\title{
Corporate social responsibility in luxury contexts: potential pitfalls and how to overcome them
}

\author{
Jenni Sipilä ${ }^{1}$ (D) Sascha Alavi ${ }^{2} \cdot$ Laura Marie Edinger-Schons $^{3} \cdot$ Sabrina Dörfer ${ }^{2} \cdot$ Christian Schmitz $^{2}$
}

Received: 25 October 2018 / Accepted: 2 November 2020 / Published online: 15 December 2020

(C) The Author(s) 2020

\begin{abstract}
Recent marketing research has identified mixed effects of luxury companies' corporate social responsibility (CSR) engagement on customer-level outcomes. To gain a better understanding of these effects, we develop a conceptual framework in which we propose that, unless carefully implemented, CSR engagement leads to lower financial performance, decreased customer loyalty, and elevated extrinsic CSR attributions for luxury companies. These effects are exacerbated if consumers actively deliberate on the company's CSR efforts. However, luxury companies can mitigate these pitfalls and reap the potential rewards of CSR engagement by (1) engaging in company-internal, especially employee-focused CSR instead of company-external, philanthropic CSR or (2) framing their brands as sustainable instead of exclusive. We find consistent support for our theorizing in five empirical studies. The results contribute to existing knowledge on stakeholder reactions to luxury brands' CSR and can help managers successfully navigate the implementation of CSR in luxury contexts.
\end{abstract}

Keywords Corporate social responsibility (CSR) - Luxury companies · Extrinsic CSR attributions · Company-internal CSR · Sustainability $\cdot$ Framing

\section{Introduction}

In light of changing social norms and customers' overwhelming demand for more responsible business practices (EpsteinReeves 2010), companies are increasingly engaging in corporate social responsibility (CSR) activities (Nielsen 2014). Luxury companies are no exception to this trend and have invested significantly in CSR, often in the form of philanthropic support for social causes. For example, the top 10 luxury companies in the Thomson Reuters ASSET4ESG database increased their donations by $12 \%$ from 2006 to 2011
(Thomson Reuters 2016). A similar trend is reflected in the recent CSR reports of major luxury firms: Tiffany \& Co., for instance, allocated \$7.9 million to charitable giving in 2016 (Tiffany and Co. 2016), Richemont donated $€ 28$ million in 2017 (Richemont 2017), and Burberry donated $£ 22.3$ million to charitable activities between 2012 and 2017 (Burberry 2017). As these figures demonstrate, luxury companies simply cannot afford to ignore the rising pressure to take greater social responsibility (Winston 2016).

Yet, to date, most research on the effectiveness of CSR has been conducted in non-luxury contexts. Moreover, the few

Maura Scott served as Area Editor for this article.

Jenni Sipilä

jenni.sipila@lut.fi

Sascha Alavi

sascha.alavi@rub.de

Laura Marie Edinger-Schons

schons@bwl.uni-mannheim.de

Sabrina Dörfer

sabrina.doerfer@rub.de
Christian Schmitz

christian.schmitz@rub.de

1 School of Business and Management, LUT University, Mukkulankatu 19, 15210 Lahti, Finland

2 Sales Management Department, Ruhr-University of Bochum, Universitätsstraße 150, 44801 Bochum, Germany

3 Chair of Sustainable Business, University of Mannheim, Schloss, SO 103, 68131 Mannheim, Germany 
studies that do consider CSR in the luxury context have yielded mixed findings. Some studies highlighted the positive effects of tying the purchase of a luxury product to a good cause (Hagtvedt and Patrick 2016) or pairing a luxury product with an environmental claim (Steinhart et al. 2013), suggesting CSR might enhance consumer outcomes in the luxury context. Other studies, however, have found the opposite effects (Torelli et al. 2012), noting that consumers perceive luxury items as less desirable when they are labeled as sustainable (Voyer and Beckham 2014) or use recycled materials (Achabou and Dekhili 2013). These opposing findings form the starting point of our investigation into how CSR affects luxury brands' firm- and customer-level outcomes.

To advance our understanding of CSR in luxury contexts, we propose a novel conceptual framework in which we argue that, unless carefully implemented, CSR will have negative consequences for luxury companies' financial performance. In particular, we argue that consumers may perceive CSR and luxury as conflicting concepts (Torelli et al. 2012) and thus attribute luxury companies' CSR to extrinsic motives like increasing profits (Du et al. 2010). These perceptions are further strengthened when consumers have time to deliberate on the company's CSR engagement. However, we also suggest that companies can prevent such a CSR backlash and reap the full rewards of their CSR engagement by (1) engaging in company-internal, employeefocused CSR instead of company-external, philanthropic CSR or (2) using cues to frame the brand as sustainable rather than exclusive (Kapferer and Michaut-Denizeau 2014).

To test these propositions, we conduct five empirical studies. First, in Study 1, we aim to determine whether CSR's harmful effects are evident at the level of objectively measured firm performance. Using secondary CSR data on 179 luxury companies, we find that, on average, CSR reduced the companies' financial performance over several years. In the subsequent studies, we examine the potential customer-level mechanisms that might explain this negative result. More specifically, in Study 2, we conduct a field experiment and find that customers' extrinsic CSR attributions were higher when a luxury company engaged in CSR, which subsequently lowered loyalty intentions. In Study 3, we generate a more detailed account of these extrinsic attributions and find they were even higher when consumers evaluated a luxury company's CSR efforts after deliberating on them (rather than making an immediate evaluation). Accordingly, Studies 4 and 5 focus on identifying remedial strategies to avoid a CSR backlash, thus allowing luxury companies to reap the maximum potential rewards of CSR engagement.

This research contributes to the CSR literature, most of which, as noted, has been conducted in non-luxury contexts (Janssen et al. 2014). While prior research has clarified the diverse benefits of CSR engagement on customer and financial outcomes (e.g., Habel et al. 2016), our study shows that luxury companies may not automatically enjoy these benefits unless they employ a carefully crafted CSR strategy that is tailored to the luxury context. In this regard, we make three specific contributions. First, by showing that luxury companies' CSR activities may elicit consumers' extrinsic CSR attributions and have long-term implications for consumer behavior, we extend previous research that suggests that CSR may momentarily enhance purchase intentions at the point of sale (Hagtvedt and Patrick 2016). Second, our findings also extend past work on the potential pitfalls of CSR in luxury contexts; in doing so, they answer the call for a long-term investigation of this topic, as research in this area has focused on immediate brand evaluations rather than on consumers' CSR attributions and longer-term loyalty intentions (Torelli et al. 2012). Third, we add to the literature on CSR attributions (Ellen et al. 2006; Forehand and Grier 2003) by showing that extrinsic CSR attributions can arise at the point of sale but are increased even further when consumers have time to deliberate on a company's CSR engagement, thus revealing the dynamic nature of extrinsic attributions.

Our results highlight the potential pitfalls that managers must consider when employing CSR in the luxury context, including reduced financial performance, elevated extrinsic CSR attributions, and reduced customer loyalty. To learn about managers' current intuitions regarding the most effective way to engage in CSR in the luxury context (the questionnaire is shown in Web Appendix A), we surveyed 48 managers from various countries, the largest representations being from the UK $(31.30 \%)$ and Germany $(20.80 \%)$. The managers worked in different industries and were acquired through personal contacts and the survey site Prolific ( $M_{\text {age }}=33.88$ years, $41.70 \%$ female). We found that the managers' intuitions were mixed and potentially harmful for both firm- and customer-level outcomes. For example, when asked whether they expected company-internal or company-external CSR activities to be more beneficial in terms of customer outcomes, most managers (58.30\%) chose the latter. Yet, in contrast to this gut feeling, our results show that engaging in companyinternal, especially employee-focused CSR (rather than company-external, philanthropic CSR) can increase luxury companies' customer loyalty by $19.68 \%$. Furthermore, most managers $(54.40 \%)$ reported that they would frame a luxury brand as exclusive. Again, our findings suggest that, contrary to this managerial intuition, framing the luxury brand as sustainable (instead of exclusive) can improve customer loyalty by $25.48 \%$. Thus, our results can help managers of luxury companies to make better informed decisions about their CSR engagement, reducing its involved risks and enhancing its rewards.

\section{The conceptual framework: CSR in luxury contexts}

Our conceptual framework centers on the consequences of luxury companies' CSR activities. In line with previous 
conceptualizations, we understand luxury brands to mean brands that offer authentic value; have high quality, a prestigious image, and premium prices; and inspire a deep connection with the consumer (Ko et al. 2017). Unlike utilitarian consumption, which is mainly motivated by "the desire to fill a basic need or accomplish a functional task," the consumption of luxury brands has a distinctly hedonic appeal, motivated by "the desire for sensual pleasure, fantasy and fun" (Strahilevitz and Myers 1998, p. 436). At the same time, however, hedonic appeal is only one factor in luxury consumption as luxury brands also reflect symbolic dominance over others, elite status, and an "aura" of authenticity (Dion and Arnould 2011), as well as exclusivity and prestige (Dubois et al. 2001).

The second key construct of this paper, CSR, refers to "actions that appear to further some social good, beyond the interests of the firm and that which is required by law" (McWilliams and Siegel 2001, p. 117; Habel et al. 2016). CSR emphasizes the values of universalism and benevolence, as well as concern for the welfare of others and the environment (Janssen et al. 2014). In this way, CSR is related but nevertheless different from the concept of sustainable development, defined as "development that meets the needs of the present without compromising the ability of future generations to meet their own needs" (World Commission on Environment and Development 1987). In recent years, awareness of urgent sustainability issues (e.g., climate change) has significantly increased. Accordingly, many companies now address these issues by referring to the United Nations Sustainable Development Goals (the "SDGs") within their CSR strategies. Thus, sustainability is the target of many CSR activities, but it is not synonymous with CSR. In what follows, we detail our hypotheses on the relationships between luxury and CSR.

\section{The effects of CSR on firm- and customer-level out- comes in luxury contexts}

We start our investigation with the aim of determining whether CSR engagement has a positive or negative influence on luxury brands' financial performance over time. We theorize that a negative effect might dominate in the long term, based on the psychological processes that consumers engage in upon encountering luxury companies' CSR activities, as outlined below.

Previous literature (Janssen et al. 2014, 2017; Torelli et al. 2012) suggests that customers may, under certain conditions, perceive CSR and luxury as incompatible concepts. Many consumers feel that luxury brands promote superficial lifestyles, encourage overconsumption, and symbolize wealth inequality (Janssen et al. 2017), while also encouraging dominance over others, hedonism, and social distance (Dion and Arnould 2011). Conversely, CSR is associated with very different values, such as social justice, environmental protection, and equality (Torelli et al. 2012). Therefore, consumers may be skeptical of luxury brands that present themselves as "caring" and "prosocial" through CSR initiatives, questioning whether this CSR engagement is in fact motivated by self-interest (Achabou and Dekhili 2013) and even developing perceptions of corporate hypocrisy (Forehand and Grier 2003; Skarmeas and Leonidou 2013). We therefore propose that many consumers attribute luxury companies' CSR engagement to extrinsic motives, such as gaining competitive advantage or increasing the firm's profits (Du et al. 2007).

These extrinsic CSR attributions may lead to decreased loyalty (Vlachos et al. 2009; Vlachos et al. 2013) via several psychological mechanisms. First, consumers might feel that the company is taking advantage of the supported cause in order to manipulate its customers (Vlachos et al. 2009). Second, when consumers perceive a company's identitydefining CSR as extrinsically motivated, they are likely to doubt the authenticity of the identity itself; this sense of authenticity and trustworthiness is an important factor in consumers' purchase decisions (Bhattacharya and Sen 2003). Moreover, as corporate communications are a key source of information about a company's identity (Bhattacharya and Sen 2003), consumers' perception that the CSR activities being communicated are extrinsically motivated is likely to exacerbate mistrust of the company's identity and, in turn, undermine consumers' loyalty.

Customer loyalty is a vital consideration, given that maintaining long-term customer relationships is crucial to long-term financial success (e.g., Reichheld and Sasser 1990; Reinartz and Kumar 2000; Wieseke et al. 2014) and growth (Keiningham et al. 2008). Indeed, if companies aim to be financially successful in the long run, they must build a loyal customer base rather than focus on constantly acquiring new customers (Schmitz et al. 2020). Thus, when customers perceive a luxury company's CSR activities as extrinsically motivated and are less loyal to the company, it is likely to harm the firm's long-term financial success through decreased sales revenue growth. Hence, from the company perspective, we hypothesize that:

H1: CSR engagement has a negative effect on the sales revenue growth of luxury companies.

Furthermore, from the customer perspective, we hypothesize that the negative effect of CSR in luxury contexts manifests in decreased loyalty intentions, and that this effect is mediated by increased extrinsic CSR attributions. Formally, we express this theory as follows:

H2: CSR engagement will result in lower loyalty intentions for luxury brands than for non-luxury brands.

H3: For luxury brands, CSR engagement will reduce loyalty intentions via increased extrinsic CSR attributions. 


\section{The exacerbating role of deliberation in consumers' CSR attributions}

Thus far, we have hypothesized that CSR engagement has a negative effect on luxury companies' long-term sales revenue growth and that this effect is due to customers' extrinsic CSR attributions and the subsequent reduction in their loyalty intentions. To gain a fuller understanding of the drivers of the longerterm outcomes of CSR engagement, we now turn to the question of how consumers' evaluations of luxury companies' CSR activities develop, particularly after a period of deliberation.

We argue that as consumers deliberate on a luxury company's CSR, their extrinsic CSR attributions will become even more salient; hence, their loyalty intentions will be reduced even further than at the immediate point of purchase. This is because at the point of purchase, consumers are often under time pressure (Suri and Monroe 2003) and focus primarily on interacting with the salesperson (Campbell and Kirmani 2000) and justifying their purchase of a luxury product to themselves (Hagtvedt and Patrick 2016). These considerations leave fewer cognitive resources available for critically deliberating on the company's motives for engaging in CSR. Therefore, we posit that consumers start to develop extrinsic CSR attributions at the point of purchase, but these attributions will become even more pronounced after the immediate point of purchase as cognitive resources become available for a more elaborate processing of the company's CSR engagement. Such processing may result in a stronger resistance to the positive message conveyed by CSR (Rifon et al. 2004), thereby increasing the perception that the company is only engaging in good deeds to gain a competitive advantage. We encapsulate these arguments in the following hypothesis:

H4: Consumers' extrinsic CSR attributions are more pronounced and loyalty intentions are lower when consumers deliberate on a luxury company's CSR engagement, compared with an immediate evaluation.

\section{The moderating role of CSR type}

Despite the potential negative effects of CSR on luxury companies' performance, as noted, these companies cannot simply ignore their stakeholders' emerging CSR expectations (Winston 2016). The question then arises: How can luxury firms alleviate the negative effects and reap the rewards of CSR engagement? To answer this question, we examine the different types of CSR activities available to luxury companies, differentiating between those that are company-internal and those that are company-external. Company-internal CSR activities are related to the business processes of the company; for example, they may focus on the well-being of employees (Turker 2009). In contrast, company-external CSR activities, such as corporate philanthropy, are targeted toward external stakeholders rather than the company's business processes (Hameed et al. 2016).

Traditionally, company-external CSR has been the most popular and prototypical of the two types as it is quick and easy to implement and does not require substantive organizational change (Peloza and Shang 2011; Schons et al. 2017). However, we argue that, for luxury companies, external (vs. internal) CSR activities are likely to exacerbate consumers' extrinsic CSR attributions because they are often less aligned with the concept of luxury than internal CSR activities. For instance, while treating employees well is perceived as a core responsibility for companies in general (Schons et al. 2017), this might be particularly true for luxury companies that symbolize craftsmanship and artisanal methods (Ko et al. 2017) and therefore depend on the talent and well-being of their employees (Kapferer and Michaut-Denizeau 2014). When the type of CSR fits with the company's activities (i.e., it is perceived as reinforcing the company's ability to produce and deliver its products), it is more likely to be seen in a positive light (Sen and Bhattacharya 2001). Thus, when luxury companies engage in company-internal CSR, consumers might perceive less of a conflict between the concepts of CSR and luxury (Kapferer and Michaut-Denizeau 2014), compared to when they focus on company-external CSR activities that do not seem to have a link to the company's operations (e.g., philanthropic donations). In sum, we propose the following hypothesis:

H5: Compared to company-external CSR, luxury companies' internal CSR engagement lowers consumers' extrinsic CSR attributions and subsequently increases loyalty intentions.

\section{The moderating role of the framing of luxury brands}

Like the concept of CSR, the concept of luxury is multifaceted (Kapferer and Michaut 2015), allowing for various brand framing approaches. We propose that some of these approaches enable luxury brands to avoid the potential negative consequences of CSR engagement, while others are likely to aggravate them. Specifically, we argue that the values of social justice, environmental protection, and equality reflected in CSR (Torelli et al. 2012) may conflict particularly strongly with luxury firms that employ an exclusivity-focused brand framing (Kapferer and Michaut 2015) because the exclusivity of luxury products signals a sense of elite privilege (Dion and Arnould 2011). Research on brand management suggests that committing to a certain brand framing (e.g., exclusivity) requires companies to use cues that are consistent with that framing (Hagtvedt and Patrick 2009). Cues that are inconsistent (e.g., CSR information that reflects social justice, environmental protection, and equality, combined with a brand 
framing that focuses on exclusivity) are therefore likely to elicit negative reactions (Buchanan et al. 1999). Thus, we posit that the potentially harmful effect of CSR through increased extrinsic CSR attributions is heightened by the extent to which the luxury brand employs an exclusivity-focused brand framing (i.e., an exclusivity framing). The perceived conflict between the concepts of luxury and CSR should be particularly strong for such brands, leading to increased extrinsic CSR attributions and reduced loyalty.

On the other hand, luxury brands may also utilize cues that are better aligned with the values represented by CSR in their brand framing; for example, they may focus on sustainability in their brand communications, as both Tesla and Stella McCartney have done to great effect (Kapferer and Michaut 2015). Framing a luxury brand around sustainability (i.e., a sustainability framing) is a clear expression of a company's concern for the common good and the well-being of both current and future generations, which harmonizes the brand with the concept of CSR (Janssen et al. 2014). In this way, luxury brands may be able to prevent contradictions between the concepts of CSR and luxury (Kapferer and MichautDenizeau 2014; Kapferer and Michaut 2015). Hence, customers are likely to have lower extrinsic CSR attributions and higher loyalty intentions toward a luxury brand that is framed as sustainable rather than exclusive. We formally hypothesize this theory as follows:
H6: Compared to an exclusivity framing, a sustainability framing reduces extrinsic CSR attributions and subsequently improves customer loyalty for luxury brands.

To test our hypotheses, we conducted five studies, described in detail below. Figure 1 depicts the conceptual framework and the study roll-out.

\section{Study 1: The negative effect of CSR on luxury companies' long-term financial performance}

\section{Dataset}

The purpose of Study 1 was test H1 and to clarify whether CSR in the luxury context reduces sales revenue growth over time. To examine the effect of CSR on luxury companies' financial performance, we merged data from Thomson Reuters' ASSET4ESG and Datastream databases. The ASSET4ESG database is one of the largest and most comprehensive sources of CSR data available, while Datastream comprises a large array of firm financial performance data over several years. Using these sources, we created a longitudinal dataset that matches CSR ratings and sales revenues over a 10-year period (from 2002 to 2011), comprising 258 firms in total. We focused our main analysis on the years from 2007 to

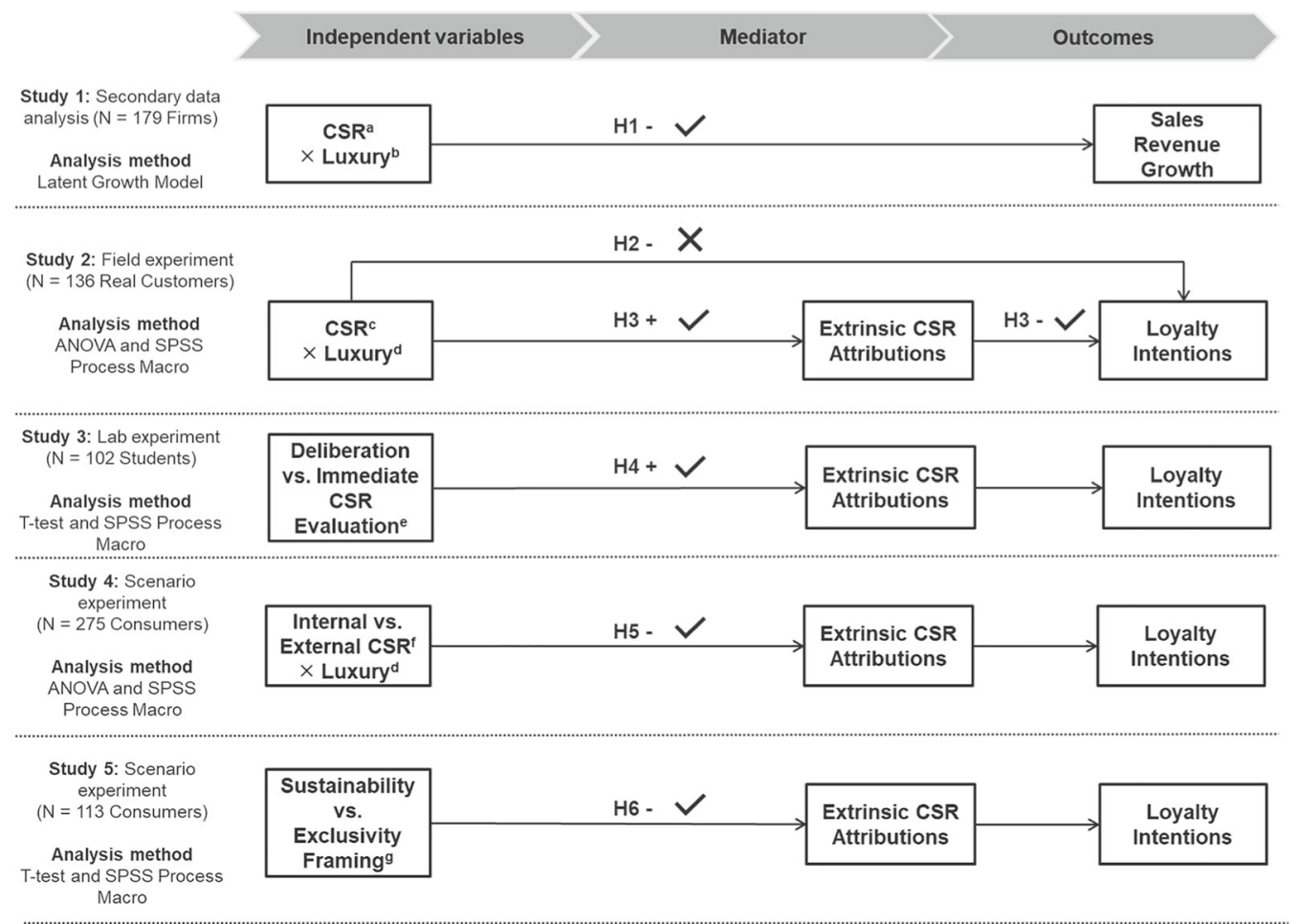

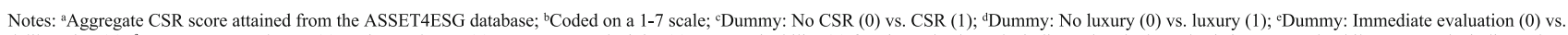
deliberation (1); fDummy: External CSR (0) vs. internal CSR (1); gDummy: Exclusivity (0) vs. Sustainability (1) framing. Check marks indicate that the hypothesis is supported, while cross marks indicate that the hypothesis is not supported.

Fig. 1 Conceptual framework and research models 
2011 since the number of available firms in the dataset was highest for this time period $(n=179)$. Further, we included only business-to-consumer firms because the two focal phenomena in our paper, luxury and CSR, are considerably more prevalent in consumer settings than in business-to-business settings. The companies ranged in size from under $5000 \mathrm{em}-$ ployees to over 100,000, and their marketing expenditures in 2007 ranged from under 100 million \$ to 1 billion \$. The companies' CSR scores (obtained from the Thomson Reuters' ASSET4ESG database) were relatively evenly distributed, with $32.40 \%$ of the companies receiving a low score of $0-33 \%, 28.80 \%$ receiving a medium score of $34-66 \%$, and $38.80 \%$ receiving a high score of $67-100 \%$.

\section{Measures}

To enable us to investigate the effect of CSR on the development of luxury firms' financial performance, the key variables in the dataset were (1) firm financial performance, (2) a firm's CSR rating, and (3) the level of luxuriousness of the firm's brand and products.

Firm financial performance We operationalized firm financial performance through firms' sales revenue growth, derived over consecutive years from Datastream. We focused on sales revenue growth as the dependent variable because, out of all the available variables in the Datastream database, sales revenue growth most directly reflects customers' purchase behaviors. This variable also constitutes an established operationalization of firm financial performance (Capon et al. 1990; McGuire et al. 1988) and fits with our study goals, as firms often aim at boosting sales revenues through an improved social image (Waddock and Graves 1997). Furthermore, to verify the robustness of our findings across different financial performance indicators, we used brand value growth as an alternative dependent variable in an additional analysis (provided in Web Appendix B).

CSR The CSR measure in this dataset is based on the ASSET4ESG database and reflects a company's capacity to maintain its license to operate by being a good citizen (based on donations of cash, goods, staff time, etc.), protecting public health (based on avoidance of industrial accidents, etc.), and respecting business ethics (based on avoiding bribery and corruption, etc.). These CSR sub-dimensions were merged into an aggregate CSR score ranging from $0 \%$ (if the company does not engage in CSR at all) to $100 \%$ (if the company engages in all CSR dimensions intensively).

Luxury context Two independent researchers rated the companies in the dataset according to the level of their brands' and products' luxuriousness. In light of research showing that customers' perceptions of luxury brands are highly differentiated and subjective (Hudders et al. 2013), we refrained from using a dichotomous coding and instead employed a scale from 1 (not at all luxurious) to 7 (very luxurious). In line with prior research, we instructed the raters to base their ratings on the price, prestige, and quality of the firm's brands and products (Dubois et al. 2001). The interrater reliability for the level of luxuriousness of firms' brands and products was .81, indicating that the raters largely agreed on the classification of the firms. The raters were blind to the study's goals. We provide the list of companies and the coding of luxuriousness for each company in Web Appendix C.

Control variables We included control variables commonly regarded as potential explanatory variables in the context of financial performance, which we also extracted from Datastream: the logged value of average marketing expenditures in the respective year, return on assets (ROA) from the previous year, and the logged value of the number of employees (which serves as a proxy for firm size and visibility). Importantly, beyond the focal CSR score at the first year of analysis, which was the key predictor in the longitudinal model, we controlled for the CSR scores in subsequent years.

\section{The analytical approach: Latent growth modeling}

Because we were interested in how a firm's CSR engagement at a certain point in time affects the development of sales revenue growth in the following years, a latent growth analysis was ideally suited to our research question (Bollen and Curran 2006). Growth modeling is regularly applied in psychological and organizational research (e.g., Bindl et al. 2012; Chan and Schmitt 2000) and has been particularly recommended for examining longitudinal data in marketing research (Palmatier et al. 2013; Steenkamp and Baumgartner 2000). In this way, a growth curve analysis is especially powerful for assessing how a predictor (e.g., the interaction of CSR and luxury) affects the growth trajectory of a dependent variable (e.g., sales revenue growth). A latent growth model is characterized by two latent factors that comprise the dependent variable at consecutive measurement points: an intercept factor and a slope factor. While the intercept factor represents the level of the dependent variable at the first measurement point (in common specifications), the slope factor represents the growth of the dependent variable over the consecutive measurement points. To explain inter-firm differences in the growth trajectories, time-invariant and time-varying variables may be added as predictors of the intercept and the slope.

With respect to our research question, the latent intercept represents the level of firms' sales revenue for the first year of the analysis. The latent slope reflects the development of firms' sales revenues over the years in the analysis. To test $\mathrm{H} 1$, we added the luxury variable, the CSR score prior to the first sales revenue measurement point, and the interaction 
effect of both variables as key predictors of the latent sales revenue intercept and slope. In addition, we included the logged value of the average marketing expenditures per year in this time period, the logged value of the number of employees in this time period, and the ROA in the initial year as time-invariant covariates. To account for firms' CSR activity after the initial year of the time period of the analysis, we included the respective CSR scores as time-varying control factors. To control for a potential nonlinear growth process, we included a quadratic growth factor in the model.

Given that latent growth models should include at least four measurement points, we focused our main analysis on the years from 2007 to 2011 since the number of available firms in the dataset was highest for this time period $(n=179)$. However, we verified the results for the previous time periods comprising lower sample sizes $\left(n_{2002-2006}=84 ; n_{2004-2008}=134 ; \mathrm{Web}\right.$ Appendices D and E). Our analysis involved four steps for careful assessment of the results' robustness: (1) we ran the previously described latent growth model with no control variables, including only the initial CSR score, the degree of luxuriousness, and the interaction term of both as predictors of the latent sales revenue intercept and slope; we then proceeded in a stepwise manner adding (2) time-invariant controls only, (3) time-varying controls only, and finally (4) both types of control variables.

\section{Results}

The results of the latent growth model estimations support $\mathrm{H} 1$ (Table 1 presents descriptive statistics and Table 2 gives the full results). For the interpretation of the results, we draw on the full model (Step 4). The model fits the data well $(\mathrm{CFI}=.96, \mathrm{TLI}=.92, \mathrm{SRMR}=.04, \mathrm{RMSEA}=.08) . \mathrm{We}$ found a negative interaction effect of CSR and luxury on sales revenue growth - that is, on the slope factor in the latent growth model ( $\beta=-.07, p=.03$; throughout this manuscript, we use $\beta$ as a symbol for standardized coefficients and $b$ for unstandardized coefficients). We visualize the interaction in Fig. 2. An inspection of the simple slopes of the effect of CSR on sales revenue growth at different values of luxuriousness indicates that CSR indeed significantly or marginally significantly reduces sales revenue growth at higher levels of luxury, that is, when the luxuriousness of a company's brands and products is rated as $7(\beta=-.28, p=.03), 6(\beta=-.22$, $p=.04)$, or $5(\beta=-.17, p=.06)$ on a seven-point scale but not when luxuriousness is rated as $4(\beta=-.12, p=.13), 3$ $(\beta=-.07, p=.34), 2(\beta=-.02, p=.77)$, or $1(\beta=.03$, $p=.77)$. The corroboration of $\mathrm{H} 1$ replicates across all robustness models estimated in the time period 2007-2011. Furthermore, we ran the identical sequential model analysis procedure for the time periods 2002-2006 and 2004-2008 (Web Appendices D and E) and the results again corroborate H1. Additionally, to verify the robustness of our findings across different financial performance indicators, we ran a similar analysis with brand value growth as a dependent variable (Web Appendix B). Again, the results confirm the negative effect of CSR on luxury companies' financial performance.

\section{Discussion}

We designed Study 1 to determine whether investing in CSR efforts is worthwhile for luxury companies. In this respect, we

Table 1 Study 1: Correlations, means, and standard deviations of the core constructs

\begin{tabular}{|c|c|c|c|c|c|c|c|c|c|c|c|c|c|}
\hline Variables & 1 & 2 & 3 & 4 & 5 & 6 & 7 & 8 & 9 & 10 & 11 & 12 & 13 \\
\hline 1. CSR 2007 & - & & & & & & & & & & & & \\
\hline 2. CSR 2008 & $.67 * *$ & - & & & & & & & & & & & \\
\hline 3. CSR 2009 & $.64 * *$ & $.81 * *$ & - & & & & & & & & & & \\
\hline 4. CSR 2010 & $.57 * *$ & $.67 * *$ & $.78 * *$ & - & & & & & & & & & \\
\hline 5. CSR 2011 & $.57 * *$ & $.58 * *$ & $.72 * *$ & $.79 * *$ & - & & & & & & & & \\
\hline 6. Sales revenue 2008 & $.35 * *$ & $.30 * *$ & $.32 * *$ & $.21 * *$ & $.33 * *$ & - & & & & & & & \\
\hline 7. Sales revenue 2009 & $.35^{* *}$ & $.30 * *$ & $.30 * *$ & $.20 * *$ & $.33 * *$ & $.97 * *$ & - & & & & & & \\
\hline 8. Sales revenue 2010 & $.36 * *$ & $.31 * *$ & $.31 * *$ & $.22 * *$ & $.34 * *$ & $.96^{* *}$ & $.99 * *$ & - & & & & & \\
\hline 9. Sales revenue 2011 & $.42 * *$ & $.29 * *$ & $.27 * *$ & $.22 * *$ & $.34 * *$ & $.98 * *$ & $.98 * *$ & $.98 * *$ & - & & & & \\
\hline 10. Firm luxury & .05 & -.02 & .05 & .00 & .03 & -.08 & -.10 & -.11 & -.12 & - & & & \\
\hline 11. Average marketing expenditures (ln) & .15 & $.19 *$ & .15 & .12 & .21 & $.25 * *$ & $.25 * *$ & $.25 * *$ & .17 & -.16 & - & & \\
\hline 12. No. employees $(\ln )$ & $.42 * *$ & $.39 * *$ & $.41 * *$ & $.32 * *$ & $.25 * *$ & $.66 * *$ & $.64 * *$ & $.66^{* *}$ & $.64 * *$ & .02 & .04 & - & \\
\hline 13. Return on assets 2007 & .07 & -.09 & -.04 & .04 & .09 & -.10 & -.11 & -.10 & -.10 & $.19^{*}$ & $-.26 * *$ & -.02 & - \\
\hline M & 50.42 & 55.94 & 60.43 & 60.29 & 61.96 & 135.35 & 137.83 & 144.02 & 134.03 & 2.53 & 19.69 & 9.83 & .09 \\
\hline SD & 29.95 & 30.67 & 30.57 & 30.47 & 29.68 & 191.14 & 199.92 & 199.90 & 139.80 & 1.49 & 2.43 & 1.50 & .07 \\
\hline
\end{tabular}

$* p<.10, * * p<.05, * * * p<.01$ (two-tailed), $\mathrm{M}=$ Mean, $\mathrm{SD}=$ standard deviation, Sales revenues measured in 100 million $\$$ 
Table 2 Study 1: Results of latent growth models 2007-2011

\begin{tabular}{|c|c|c|c|c|c|c|}
\hline Path & & No controls & $\begin{array}{l}\text { Time-invariant } \\
\text { controls only }\end{array}$ & $\begin{array}{l}\text { Time-variant } \\
\text { controls only }\end{array}$ & $\begin{array}{l}\text { Time-variant } \\
+ \text { invariant } \\
\text { controls }\end{array}$ & Hypoth. test \\
\hline \multicolumn{7}{|c|}{ Hypothesized effects on sales revenue growth } \\
\hline CSR 2007 & $\rightarrow$ Sales revenue growth & $-.01^{\mathrm{ns}}$ & $.06^{\mathrm{ns}}$ & $-.07^{\mathrm{ns}}$ & $-.05^{\mathrm{ns}}$ & \\
\hline Luxury & $\rightarrow$ Sales revenue growth & $-.04^{*}$ & $-.07^{* * * *}$ & $-.03^{\mathrm{ns}}$ & $-.03^{\mathrm{ns}}$ & \\
\hline CSR $2007 \times$ Luxury & $\rightarrow$ Sales revenue growth & $-.06^{* *}$ & $-.10^{* * *}$ & $-.06^{* *}$ & $-.07^{* *}$ & H1: confirmed \\
\hline \multicolumn{7}{|c|}{ Hypothesized effects on sales revenue intercept } \\
\hline CSR 2007 & $\rightarrow$ Sales revenue intercept & $.34^{* * * *}$ & $.08^{* *}$ & $.23^{*}$ & $.12^{\mathrm{ns}}$ & \\
\hline Luxury & $\rightarrow$ Sales revenue intercept & $-.10^{* *}$ & $.03^{\mathrm{ns}}$ & $-.10^{* * * *}$ & $-.07^{* * * *}$ & \\
\hline CSR $2007 \times$ Luxury & $\rightarrow$ Sales revenue intercept & $-.12^{* * * *}$ & $-.02^{\mathrm{ns}}$ & $-.11^{* * * *}$ & $-.07^{* *}$ & \\
\hline \multicolumn{7}{|c|}{ Controlled effects on sales revenue (quadratic) growth } \\
\hline CSR 2007 & $\begin{array}{l}\rightarrow \text { Sales revenue quadratic } \\
\text { growth }\end{array}$ & $.05^{\mathrm{ns}}$ & $-.04^{\mathrm{ns}}$ & $.17^{* *}$ & $.13^{*}$ & \\
\hline Luxury & $\begin{array}{l}\rightarrow \text { Sales revenue quadratic } \\
\text { growth }\end{array}$ & $.04^{*}$ & $.09^{* * *}$ & $.03^{\mathrm{ns}}$ & $.03^{\mathrm{ns}}$ & \\
\hline CSR $2007 \times$ Luxury & $\begin{array}{l}\rightarrow \text { Sales revenue quadratic } \\
\text { growth }\end{array}$ & $.07^{* * *}$ & $.11^{* * * *}$ & $.06^{\mathrm{ns}}$ & $.08^{* *}$ & \\
\hline Sales revenue intercept & $\rightarrow$ Sales revenue growth & $.01^{\mathrm{ns}}$ & $-.01^{\mathrm{ns}}$ & $.01^{\mathrm{ns}}$ & $-.01^{\mathrm{ns}}$ & \\
\hline \multicolumn{7}{|c|}{ Controlled effects on sales revenue intercept } \\
\hline $\begin{array}{l}\text { Average marketing } \\
\text { expenditures }(\ln )\end{array}$ & $\rightarrow$ Sales revenue intercept & & $.11^{* * * *}$ & & $.13^{* * *}$ & \\
\hline Number of employees (ln) & $\rightarrow$ Sales revenue intercept & & $.75^{* * * *}$ & & $.51^{* * * *}$ & \\
\hline Return on assets 2007 & $\rightarrow$ Sales revenue intercept & & $-.08^{* *}$ & & $-.07^{*}$ & \\
\hline \multicolumn{7}{|c|}{ Controlled effects on sales revenue growth } \\
\hline $\begin{array}{l}\text { Average marketing } \\
\text { expenditures }\end{array}$ & $\begin{array}{l}\rightarrow \text { Sales revenue growth } \\
\quad(\ln )\end{array}$ & & $.01^{\mathrm{ns}}$ & & $.00^{\mathrm{ns}}$ & \\
\hline Number of employees (ln) & $\rightarrow$ Sales revenue growth & & $-.19^{* * *}$ & & $-.07^{\mathrm{ns}}$ & \\
\hline Return on assets 2007 & $\rightarrow$ Sales revenue growth & & $.01^{\mathrm{ns}}$ & & $.02^{\mathrm{ns}}$ & \\
\hline \multicolumn{7}{|l|}{ Further controlled effects } \\
\hline $\begin{array}{l}\text { Average marketing } \\
\text { expenditures }(\ln )\end{array}$ & $\begin{array}{l}\rightarrow \text { Sales revenue quadratic } \\
\text { growth }\end{array}$ & & $.01^{\mathrm{ns}}$ & & $.02^{\mathrm{ns}}$ & \\
\hline Number of employees (ln) & $\begin{array}{l}\rightarrow \text { Sales revenue quadratic } \\
\text { growth }\end{array}$ & & $.28^{* * * *}$ & & $.14^{*}$ & \\
\hline Return on assets 2007 & $\begin{array}{l}\rightarrow \text { Sales revenue quadratic } \\
\text { growth }\end{array}$ & & $.00^{\mathrm{ns}}$ & & $-.00^{\mathrm{ns}}$ & \\
\hline $\begin{array}{l}\text { CSR score 2008/ } \\
\text { 2009/2010/2011 }\end{array}$ & $\rightarrow$ Sales revenue intercept & & & Included & Included & \\
\hline $\begin{array}{l}\text { CSR score 2008/ } \\
\text { 2009/2010/2011 }\end{array}$ & $\rightarrow$ Sales revenue growth & & & Included & Included & \\
\hline $\begin{array}{l}\text { CSR score 2008/ } \\
\text { 2009/2010/ } 2011\end{array}$ & $\begin{array}{l}\rightarrow \text { Sales revenue quadratic } \\
\text { growth }\end{array}$ & & & Included & Included & \\
\hline All autoregressive effects of & CSR Scores 2007-2011 & & & Included & Included & \\
\hline \multicolumn{7}{|l|}{ Model characteristics } \\
\hline CFI / TLI & & $1.00 / 1.00$ & $.98 / .92$ & $.98 / .94$ & $.96 / .92$ & \\
\hline SRMR / RMSEA & & $.01 / .00$ & $.01 / .09$ & $.02 / .08$ & $.04 / .08$ & \\
\hline$N=179$ & & & & & & \\
\hline
\end{tabular}

ns $p>.10, * p<.10, * * p<.05, * * * p<.01$ (two-tailed); standardized coefficients

found that CSR engagement exhibits a negative effect on firms' sales revenue growth and brand value growth. Thus, while previous literature suggests that CSR activities may increase immediate purchase intentions in the luxury context
(Hagtvedt and Patrick 2016), we show that, over time, they also lead to a sales decline and an erosion of brand value. Consequently, luxury companies might not financially benefit from CSR engagement. These findings are in line with and 
extend the work of Torelli et al. (2012), demonstrating that the negative effect of CSR efforts in the luxury context prevails over time and emerges not only for brand evaluations but also for the firms' actual financial performance. However, the question remains as to which consumerlevel psychological processes might be driving this negative long-term effect. Therefore, in Study 2 we measured consumers' extrinsic CSR attributions and loyalty intentions toward luxury brands.

\section{Study 2: The effect of CSR on customer-level outcomes}

In this second study, we tested $\mathrm{H} 2$ and $\mathrm{H} 3$ to gain insights into the effects of CSR on luxury customers' extrinsic CSR attributions and loyalty intentions. Through this investigation, we create a foundation for understanding how managers of luxury companies may avoid the downsides of CSR engagement.

\section{Method}

Experimental design and procedure To test our predictions, we conducted a field experiment in collaboration with a car retailer. The experiment followed a 2 (CSR information vs. no CSR information) $\times 2$ (luxury vs. non-luxury brand) betweensubjects design. The partner company allowed us to manipulate its frontline employees' communication strategies in real sales encounters with customers. We collected the data in one luxury car branch via two frontline employees and in one nonluxury car branch via three frontline employees. All the frontline employees were male. We manipulated CSR via information leaflets describing the company's CSR engagement and the supporting communications of the frontline employees we trained for this purpose. The information leaflets and training procedure details are provided in Web Appendix F. In the CSR condition, frontline employees informed their customers about the company's CSR engagement toward the end of the sales encounter using the leaflet, which included information about the company's CSR activities aimed at assisting disadvantaged children. The company regularly supports this social project. In the control conditions (for both luxury and nonluxury interactions), to make the interactions as comparable as possible, frontline employees omitted the CSR information and handed the customer a leaflet with general information about the company instead.

In all groups, frontline employees asked their customers to take part in a survey by filling out a questionnaire that members of the research team solicited. After 12 weeks of data collection, the response rate was approximately $75 \%$ (i.e., relatively high for a survey study in the field). The sample consisted of 136 employee-customer interactions. Customers had a mean age of 40.80 years $(S D=11.32) ; 31.60 \%$ were female and $68.40 \%$ were male. There were no systematic differences among the experimental groups in terms of their basic characteristics (Web Appendix F). As expected, however, luxury customers had a higher monthly income $(€ 10,001-15,000)$ than nonluxury customers (€2001-4000).

Measures As we collaborated with a real company during actual sales encounters, we had to keep the questionnaires concise, and employed single-item measures in many cases. At the same time - and particularly in light of the field experimental nature of this study - we deemed it important to control for various aspects of the sales situation and the participants' pre-existing attitudes in order to rule out alternative explanations for our results (Bernerth et al. 2018; Klarmann and Feurer 2018). We measured all constructs on seven-point Likert scales anchored at 1 (fully disagree) and 7 (fully agree), unless stated otherwise. First, we controlled for customers' perceptions of the salesperson's behavior, as these may have influenced customer evaluations of the company (Babin et al. 1999) as well as their loyalty toward the company (Brexendorf et al. 2010; Reynolds and Beatty 1999). We employed the following items to measure these perceptions: "The salesperson was able to help answer my questions" (perceived customer orientation, adapted from Groth et al. 2009); "The salesperson was very friendly" (warmth, Habel et al. 2017); "The salesperson put pressure on me, even though he knew that the car was not right for me" (selling orientation, adapted from Thomas et al. 2001); and "How authentic did you find the emotions displayed by the salesperson?" (the authenticity of emotional display, Hennig-Thurau et al. 2006) anchored at 1 (very inauthentic) and 7 (very authentic).

Next, we controlled for product evaluations (using the item "I would like (1)/not like (7) the car that I was examining") because these evaluations may influence customer loyalty (Suh and Yi 2006) and consumers are likely to focus on them before considering CSR information (Öberseder et al. 2011). Additionally, we controlled for the participants' general attitude toward CSR (with the item "I like it when companies regularly donate a part of their profits to charity") because this is likely to influence consumer reactions to companies' CSR activities (Bhattacharya and Sen 2004). We also controlled for customer-company identification (with the item "I feel connected with [company name]") as a feeling of connectedness to a company may affect the impact of company measures, such as CSR, on customer responses (Bhattacharya and Sen 2004). To measure loyalty, we used two items adapted from Zeithaml et al. (1996), after which we checked for the success of the CSR and luxury manipulations. As a final step, we measured demographics and thus controlled for the gender match between the salesperson and the customer, which may influence the dynamic of the sales interaction in the carretailing context. Since all the salespeople in this study were male, we controlled for gender match through the participants' 


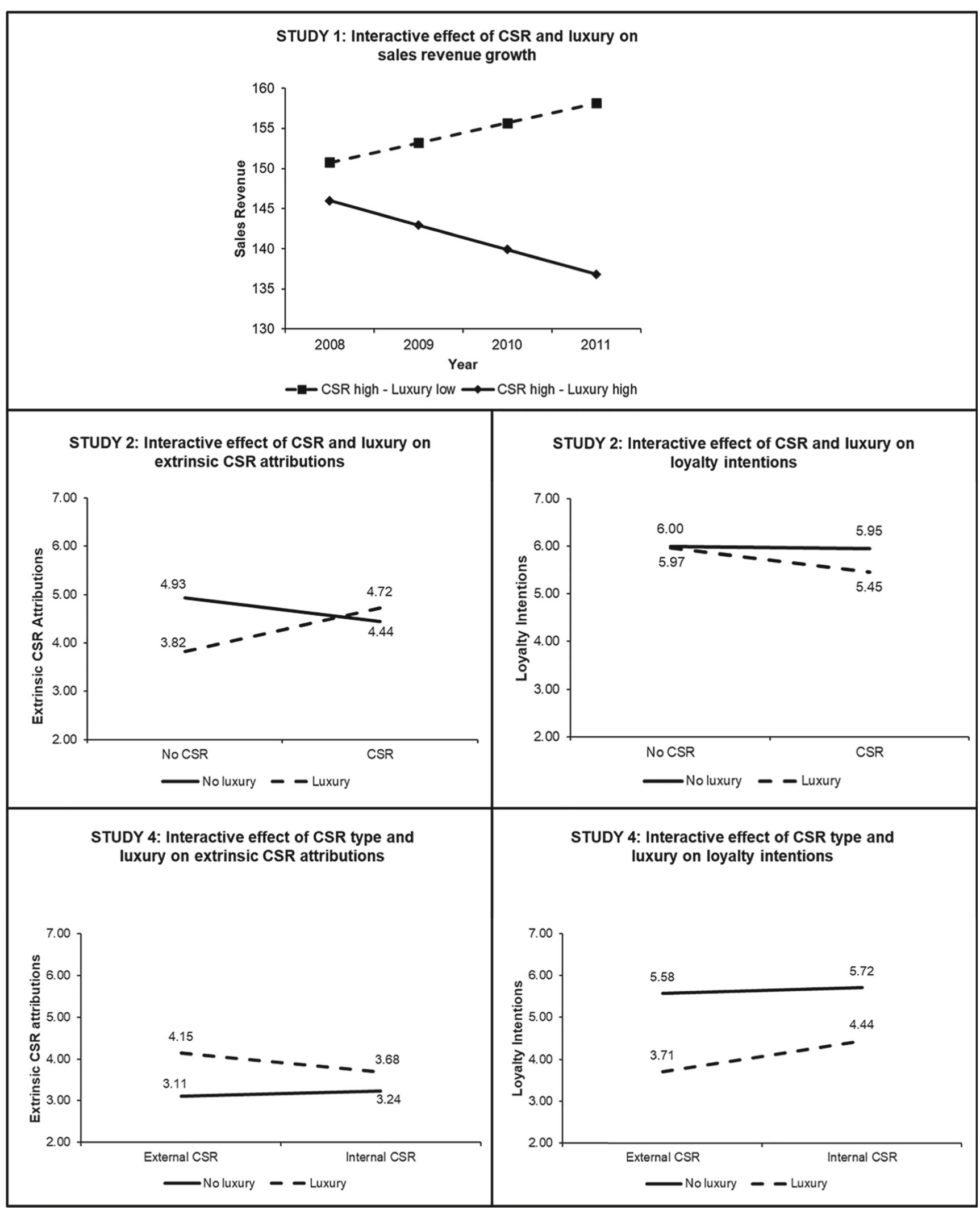

Fig. 2 Studies 1, 2, and 4: Interaction effects 
gender (coded as 0 for female and 1 for male). We report the analyses without the control variables in Web Appendix G.

All our scales exceeded the threshold value of .70 for Cronbach's alpha that is proposed in the literature (Bagozzi and Yi 1988; Nunnally 1978). Furthermore, all factor loadings for the multi-item scales were above .85 , indicating the validity of the scales, and all measures for which AVE was available fulfilled the Fornell and Larcker (1981) requirement in support of discriminant validity. The Appendix provides a comprehensive overview of the measures used in this study and the confirmatory factor analysis.

\section{Results}

Manipulation checks All the participants in the CSR group correctly indicated that they received the CSR flyer, and all the participants in the non-CSR group correctly indicated that they received the non-CSR flyer. To verify whether our luxury manipulation worked as intended, we asked participants to evaluate their perception of the luxuriousness of the product with the item "The car that I am interested in is ..." with answers ranging from 1 (not a luxury product) to 7 (a luxury product). A two-way ANOVA with the CSR and luxury dummies (i.e., the experimental groups) as independent variables and the manipulation check item as the dependent variable shows a main effect of the luxury dummy $(F(1,132)=$ $159.09, p<.001)$, indicating that luxury perceptions are higher in the luxury treatment groups $\left(M_{N o}\right.$ CSR \& luxury $=$ $6.45, S D=.74 ; M_{C S R} \&$ luxury $\left.=6.46, S D=.70\right)$ than in the non-luxury treatment groups $\left(M_{N o} C S R \&\right.$ No luxury $=3.03$, $S D=1.74 ; M_{C S R} \&$ No luxury $\left.=3.58, S D=2.15\right)$. We found no main effect of the CSR dummy $(F(1,132)=1.19, p=.28)$ and no interaction effect of the CSR and luxury dummies $(F(1,132)=1.19, p=.28)$ on the manipulation check item. Therefore, we conclude that our manipulations worked as intended.

Hypotheses testing We began our hypothesis testing for $\mathrm{H} 2$ and $\mathrm{H} 3$ with a two-way ANOVA in which luxury (coded as 1 for luxury company and 0 for non-luxury company) and CSR (coded as 1 for CSR and 0 for non-CSR) were the independent variables, loyalty intentions were the dependent variable, and the aforementioned control variables were included as covariates. This analysis revealed marginally significant main effects of luxury $(F(1,123)=3.05, p=.08)$ and CSR $(F(1,123)=3.80 p=.05)$ and a non-significant interaction effect of CSR and luxury on loyalty intentions $(F(1,123)=2.42$, $p=.12$ ). Therefore, Study 2 does not render support for $\mathrm{H} 2$. As a next step, we ran a similar two-way ANOVA with extrinsic CSR attributions as the dependent variable. The results revealed non-significant main effects of CSR $(F(1,122)=.46$, $p=.50)$ and luxury $(F(1,122)=1.83, p=.18)$ and a significant interaction of the CSR and luxury dummies on extrinsic CSR attributions $(F(1,122)=5.05, p=.03)$. Simple effects analyses reveal that in the luxury condition, extrinsic attributions were significantly higher when customers received CSR information $(M=4.72, S E=.30)$ compared to when they did not receive CSR information at the point of sale $(M=3.82$, $S E=.28), F(1,122)=4.48, p=.04$. However, in the nonluxury condition, there was no significant difference in extrinsic attributions between the CSR and non-CSR conditions $(F(1,122)=1.32, p=.25)$. We graph this interaction in Fig. 2.

Additionally, we examined whether the interaction effect of CSR and luxury on extrinsic CSR attributions subsequently leads to lower loyalty intentions using SPSS Process macro v. 2.16.3 (Hayes 2018, Model 7, 5000 bootstrap samples). In the analysis, the CSR dummy was the independent variable, the luxury dummy was the moderator, extrinsic CSR attributions were the mediator, loyalty intentions were the dependent variable, and the control variables were included as covariates. In line with $\mathrm{H} 3$, we found a significant moderated mediation (index of moderated mediation $=-.15,95 \% \mathrm{CI}:-.43,-.01$ ), indicating that the CSR dummy significantly reduces loyalty via extrinsic CSR attributions for luxury brands $(b=-.10$, $95 \%$ CI: $-.25,-.01)$, but not for non-luxury brands $(b=.05$, 95\% CI: $-.04, .24)$. We report the results in Table 3.

We provide the correlations and descriptive statistics of all key variables in Web Appendix H. Finally, to complement our analyses, we accounted for prior research that suggests CSR engagement may also reduce consumers' guilt at the point of purchase which may in turn influence their purchase intentions (Hagtvedt and Patrick 2016). We present this additional analysis in Web Appendix I.

\section{Discussion}

Overall, Study 2 corroborates our expectation that consumers attribute luxury companies' CSR to extrinsic motives, which subsequently reduces their loyalty intentions. The analysis revealed that our manipulations have an indirect-only effect on loyalty intentions (Zhao et al. 2010), whereby the effect only occurs indirectly via extrinsic CSR attributions, but the manipulations have no significant interaction effect on loyalty intentions.

We attribute the manipulations' non-significant effect on loyalty intentions to both methodological and theoretical reasons. First, from a method perspective, this study was a field experiment in which consumers had a relationship with and pre-existing attitudes toward the focal company. Therefore, despite a comprehensive set of control variables, some factors driving consumers' loyalty may have remained beyond our control, possibly reducing the strength of the direct effect of our treatments. In addition, the sample size in this study was quite small. Given a larger sample size, our direct effect might very likely have 
Table 3 Study 2: Results of moderated mediation analysis (SPSS Process Model 7)

\begin{tabular}{|c|c|c|c|c|c|}
\hline & $\begin{array}{l}\text { Unstandardized } \\
\text { coefficient }\end{array}$ & s.e. & $\mathrm{t}$ & $95 \% \mathrm{CIs}$ & Hypothesis test \\
\hline \multicolumn{6}{|l|}{ Effects on extrinsic CSR attributions } \\
\hline Luxury $^{\mathrm{a}}$ & $-1.11^{* *}$ & .43 & -2.62 & -1.95 to -.27 & \\
\hline $\mathrm{CSR}^{\mathrm{b}}$ & $-.50^{\mathrm{ns}}$ & .43 & -1.15 & -1.35 to .36 & \\
\hline CSR x Luxury & $1.40 * *$ & .62 & 2.25 & .17 to 2.63 & \\
\hline Effects on loyalty intentions & & & & & $\mathrm{H} 2$ : Not Confirmed ${ }^{\mathrm{C}}$ \\
\hline Extrinsic CSR attributions & $-.11 * *$ & .04 & -2.49 & -.19 to -.02 & \\
\hline CSR & $-.24^{\mathrm{ns}}$ & .15 & -1.67 & -.53 to .04 & \\
\hline \multicolumn{6}{|l|}{ Controlled effects on extrinsic CSR attributions } \\
\hline Consumer-company identification & $-.16^{\mathrm{ns}}$ & .10 & -1.58 & -.35 to .04 & \\
\hline Gender & $.01^{\mathrm{ns}}$ & .32 & .02 & -.62 to .63 & \\
\hline Salesperson customer orientation & $-.01^{\mathrm{ns}}$ & .25 & -.02 & -.50 to .49 & \\
\hline Salesperson warmth & $.39^{\mathrm{ns}}$ & .31 & 1.25 & -.23 to 1.01 & \\
\hline Authenticity of salesperson's emotional display & $.13^{\text {ns }}$ & .22 & .59 & -.30 to .56 & \\
\hline Salesperson selling orientation & $.19^{\mathrm{ns}}$ & .19 & 1.03 & -.18 to .57 & \\
\hline Product evaluation & $-.10^{\mathrm{ns}}$ & .19 & -.50 & -.48 to .28 & \\
\hline Attitude toward CSR & $.18^{\mathrm{ns}}$ & .12 & 1.56 & -.05 to .41 & \\
\hline \multicolumn{6}{|l|}{ Controlled effects on loyalty intentions } \\
\hline Consumer-company identification & $.08^{*}$ & .05 & 1.73 & -.01 to .17 & \\
\hline Gender & $.14^{\mathrm{ns}}$ & .15 & .89 & -.17 to .44 & \\
\hline Salesperson customer orientation & $-.06^{\mathrm{ns}}$ & .12 & -.52 & -.30 to .18 & \\
\hline Salesperson warmth & $-.14^{\mathrm{ns}}$ & .15 & -.91 & -.44 to .16 & \\
\hline Authenticity of salesperson's emotional display & $.15^{\mathrm{ns}}$ & .11 & 1.38 & -.06 to .35 & \\
\hline Salesperson selling orientation & $-.23^{\mathrm{ns}}$ & .09 & -2.62 & -.40 to -.06 & \\
\hline Product evaluation & $.14^{\mathrm{ns}}$ & .09 & 1.54 & -.04 to .32 & \\
\hline Attitude toward CSR & $.01^{\mathrm{ns}}$ & .06 & .20 & -.10 to .12 & \\
\hline \multicolumn{6}{|c|}{ Conditional indirect effects of CSR on loyalty intentions via extrinsic CSR attributions } \\
\hline No luxury & .05 & .07 & - & -.04 to .24 & \\
\hline Luxury & -.10 & .06 & - & -.25 to -.01 & \\
\hline Index of moderated mediation & -.15 & .11 & & -.43 to -.01 & H3: Confirmed \\
\hline
\end{tabular}

${ }^{\mathrm{ns}} p>.10, * p<.10, * * p<.05, * * * p<.01 ; \mathrm{CI}=$ Confidence Interval, s.e. = standard error. ${ }^{\mathrm{a}}$ Dummy: non-luxury $(0)$ vs. luxury brand (1). ${ }^{\mathrm{b}}$ Dummy: No CSR (0) vs. CSR (1). ${ }^{\mathrm{c}}$ In Study 2, prior to assessing the indirect effects through the SPSS Process Model, we conducted an ANOVA to examine direct effects of CSR, luxury, and their interaction on loyalty intentions. The ANOVA analysis revealed a non-significant interaction of CSR and luxury on loyalty intentions $(\mathrm{F}(1,123)=2.42, \mathrm{p}=.12)$. Therefore, Study 2 does not render support for $\mathrm{H} 2$

turned out to be significant. In this context, it is critical to note that (1) we find a significant moderated mediation that is in line with our core theorizing, (2) in all subsequent studies we find significant direct effects of our treatments on loyalty intentions, and (3) in our first study, we even found a negative effect of CSR and luxury on companies' performance.

Second, from a theoretical perspective, previous research has revealed mixed findings on the effect of CSR in luxury contexts; this might be due to the countervailing effects of (1) consumers' reduced guilt for the luxury purchase through CSR, which may lead to positive consumer outcomes (Hagtvedt and Patrick 2016) and (2) extrinsic attributions driven by an inconsistency between CSR and luxury, which is the focus of our study and which we believe detrimentally affects longer-term customer loyalty. The guilt reduction mechanism, which we also empirically report in Web Appendix H, can be expected to play an especially important role at the immediate point of sale, as customers focus on interacting with the salesperson and justifying their luxury purchase to themselves at that time. Notably, this finding has particular relevance for Study 2, in which consumers find themselves in a real purchase context. Therefore, we propose that the extrinsic attributions mechanism will be more pronounced when consumers do not find themselves in a real purchase situation (as in our later experiments) and have more 
time to deliberate on the company's CSR engagement. Hence, in our following studies, we use more controlled study settings as well as larger sample sizes.

The results of this study imply that the managers of luxury companies should be very cautious when designing their CSR engagement as it may increase extrinsic CSR attributions. Past research has emphasized the harmful impact of extrinsic CSR attributions on customers' attitudes toward the company (Becker-Olsen et al. 2006), beliefs about the CSR engagement (Du et al. 2007), and our outcome of interest, loyalty (Vlachos et al. 2009, 2013). In our next study, we employ a different product category and extend our investigation beyond the immediate point of purchase to understand how extrinsic CSR attributions and loyalty intentions develop when consumers deliberate on a luxury company's CSR.

\section{Study 3: The exacerbating role of deliberation in consumers' CSR attributions}

This study examines how extrinsic CSR attributions are affected by consumers' deliberation of a luxury company's CSR, thereby testing H4.

\section{Method}

Experimental design and procedure After recruiting $102 \mathrm{stu}-$ dents from a German business school $\left(M_{\text {age }}=24.10\right.$ years, $58.80 \%$ female, $40.20 \%$ male) as participants, we conducted a lab experiment using a between-subjects design adapted from Schnider et al. (2018). Specifically, we manipulated deliberation by assigning the participants to one of two groups. In one group (immediate evaluation), participants read a description of a fictitious luxury wristwatch company that engages in philanthropic CSR activities and immediately responded to a questionnaire measuring their loyalty intentions and extrinsic CSR attributions toward the company. In another group (deliberation), participants saw the same text, but before answering the questionnaire, they were asked to discuss their perceptions of the company's CSR engagement with the person sitting next to them. All treatment texts appear in Web Appendix J. Further, we checked that the two conditions did not differ in terms of CSR and luxury perceptions and report these additional checks in Web Appendix K.

Measures After the manipulation, we measured loyalty intentions on a five-item scale adopted from Zeithaml et al. (1996), and then measured extrinsic CSR attributions with three items adapted from Habel et al. (2016). Lastly, we conducted manipulation checks. We measured all constructs on seven-point Likert scales $(1=$ completely disagree, $7=$ completely agree $)$. Finally, we operationalized deliberation as a dummy variable coded as 0 for immediate evaluation and 1 for evaluation after deliberation. Both multi-item scales exceeded the threshold value of .70 for Cronbach's alpha, all factor loadings were above .72, and both measures met the Fornell and Larcker (1981) criterion. The complete list of items and scale evaluation are provided in the Appendix.

\section{Results}

We conducted an independent samples t-test with the deliberation dummy as the independent variable and loyalty intentions as the dependent variable and found that loyalty intentions were significantly lower in the deliberation condition $(M=2.96$, $S D=1.34)$ than in the immediate evaluation condition $(M=$ $3.95, S D=1.30), t(98)=3.76, p<.001$. Furthermore, we conducted a similar t-test with extrinsic CSR attributions as the dependent variable and found that these attributions were marginally higher in the deliberation condition $(M=5.17, S D=$ 1.46) than in the immediate evaluation condition $(M=4.63$, $S D=1.30), t(100)=1.94, p=.06$. To test $\mathrm{H} 4-$ that is, to determine whether extrinsic CSR attributions were higher and loyalty intentions were subsequently lower after deliberation than in the immediate evaluation condition-we used SPSS Process macro (Hayes 2018, Model 4, 5000 bootstrap samples), whereby the deliberation dummy was the independent variable, extrinsic CSR attributions were the mediator, and loyalty intentions were the dependent variable. In support of $\mathrm{H} 4$, we found a significant negative indirect effect of deliberation on loyalty intentions via extrinsic CSR attributions $(b=-.16,95 \%, \mathrm{CI}$ : $-.41,-.03)$. The correlations and means of the constructs are reported in Web Appendix L, and the full results of the mediation analysis are reported in Table 4.

\section{Discussion}

The results of this study suggest that consumers' deliberation on a company's CSR activities can reduce loyalty via increased extrinsic CSR attributions. This finding supports our theorizing that the negative effects of CSR on luxury companies' outcomes might unfold over time, thereby offering a more nuanced understanding of the customer-level processes found in Study 2 and the negative interaction of CSR and luxury on luxury companies' performance found in Study 1. From a managerial perspective, these findings raise the interesting question of what measures luxury companies can take to prevent CSR backlash-a question we seek to answer in Studies 4 and 5.

\section{Study 4: The moderating role of CSR type}

In Study 4, we examine how luxury companies may mitigate the negative effects and reap the rewards of engaging in CSR. To this end, we studied different types of CSR (i.e., companyexternal vs. company-internal CSR), and thus tested H5. 
Table 4 Studies 3-5: Mediation analysis

Unstandardized coefficient $\quad$ s.e. $\quad \mathrm{t} \quad 95 \% \mathrm{CIs} \quad$ Hypothesis test

\section{STUDY 3}

Effects on loyalty intentions

Extrinsic CSR attributions

Deliberation $^{\mathrm{a}}$

$-.30 * * * \quad .09 \quad-3.20 \quad-.48$ to -.11

Effects on extrinsic CSR attributions

Deliberation $^{\mathrm{a}}$

$-.83 * * *$

$.55^{* *}$

$-.16$

Deliberation

\section{STUDY 4}

Effects on loyalty intentions

Extrinsic CSR attributions

Luxury $^{\text {b }}$

Effects on extrinsic CSR attributions

Luxury $^{\text {b }}$

Type of CSR (internal vs. external) ${ }^{c}$

Interaction effects on extrinsic CSR attributions

Luxury $^{b} \mathrm{x}$ Type of CSR (internal vs. external) ${ }^{\mathrm{c}}$

Conditional indirect effects of luxury on loyalty intentions

$\begin{array}{lc}\text { CSR Type }=\text { Internal } & -.16 \\ \text { CSR Type }=\text { External } & -.37 \\ \text { Index of moderated mediation } & .22\end{array}$

\section{STUDY 5}

Effects on loyalty intentions

Extrinsic CSR attributions

Sustainability brand framing ${ }^{\mathrm{d}}$

$-.29 * * *$
$.90 * * *$
$-.55^{* *}$
.16

$-.29 * * *$

Effects on extrinsic CSR attributions

Sustainability brand framing ${ }^{\mathrm{d}}$

Indirect effects on loyalty intentions

Sustainability brand framing ${ }^{\mathrm{d}}$

$\begin{array}{llll}-.36^{* * *} & .05 & -7.15 & -.46 \text { to }-.26 \\ -1.35^{* * *} & .14 & -9.50 & -1.63 \text { to }-1.07 \\ & & & \\ 1.04 * * * & .23 & 4.52 & .59 \text { to } 1.50 \\ .13^{\mathrm{ns}} & .23 & .59 & -.31 \text { to } .58 \\ & & & \\ -.60^{*} & .33 & -1.82 & -1.25 \text { to } .05\end{array}$

$.08 \quad-\quad-.33$ to -.01

$.11-\quad-.63$ to -.19

$.12 \quad .00$ to .49

H5: Confirmed

ns $p>.10, * p<.10, * * p<.05, * * * p<.01 . \mathrm{CI}=$ confidence interval, s.e. $=$ standard error. ${ }^{\mathrm{a}}$ Dummy: immediate CSR evaluation $(0)$ vs. deliberation $(1)$, ${ }^{\mathrm{b}}$ Dummy: No luxury (0) vs. Luxury (1), ${ }^{\mathrm{c}}$ Dummy: External CSR (0) vs. Internal CSR (1), ${ }^{\mathrm{d}}$ Dummy: Exclusivity framing (0) vs. Sustainability framing (1). In Study 4, the ANOVA analysis revealed a significant interaction of CSR type and luxury on loyalty intentions $(\mathrm{F}(1,271)=4.14, \mathrm{p}=.04)$

\section{Method}

Experimental design and procedure We conducted an online scenario experiment with a 2 (brand: luxury vs. non-luxury) $\times$ 2 (CSR: company-internal vs. company-external) betweensubjects design. We provide all the treatment texts in Web Appendix J. The participants were 285 U.S. consumers, recruited via Prolific. We excluded 10 participants who spent less than three minutes on the questionnaire $\left(M_{\text {response time }}=\right.$ $7.83 \mathrm{~min}$.), because short response times are likely to indicate careless and inattentive responding (Geuens and De Pelsmacker 2017; Wood et al. 2017). This resulted in a final sample of 275 participants $\left(M_{\text {age }}=36.27\right.$ years, $70.20 \%$ female, $27.60 \%$ male).
Measures After the manipulations, we measured participants' loyalty intentions before also measuring extrinsic CSR attributions using the same scales as in Study 3. We then conducted manipulation checks. Both multi-item scales exceeded the value of .70 for Cronbach's alpha (Bagozzi and Yi 1988; Nunnally 1978), all factor loadings for the items were above .65 , and both measures met the Fornell-Larcker requirement. The Appendix provides a comprehensive overview of the measures and the confirmatory factor analysis.

\section{Results}

Manipulation checks To ensure that the manipulations worked as intended, we measured participants' perceptions of luxury, internal CSR, and external CSR. To verify the manipulation of 
luxury, we used the item "the company is luxurious," measured on a seven-point Likert scale. For this item, we found a significantly higher mean in the luxury group $(M=5.85, S D=$ 1.24) than in the non-luxury group $(M=3.31, S D=1.39)$, $t(273)=15.87, p<.001$. Moreover, we conducted a $2 \times 2$ ANOVA with the CSR and luxury dummies as the independent variables and the same manipulation check item as the dependent variable. The analysis revealed a significant main effect of the luxury manipulation $(F(1,271)=257.59, p<.001)$ and a significant main effect of the CSR manipulation $(F(1,271)=4.07, p=.045)$, but no significant interaction effect $(F(1,271)=.25, p=.618)$. Given the significant main effect of the CSR type on the manipulation check item, we proceeded with an analysis of effect sizes in order to compare the relative impact of each factor according to the procedure discussed in Perdue and Summers (1986), which is commonly applied in marketing research (e.g., Bellezza et al. 2014; Hildebrand et al. 2017; Taylor and Bearden 2002). The effect size of the luxury manipulation was 25 times higher $\left(\eta_{\mathrm{p}}{ }^{2}=.49\right)$ than the effect size of the CSR manipulation $\left(\eta_{\mathrm{p}}^{2}=.02\right)$, suggesting that our luxury manipulation was successful.

For internal CSR, we used the following item as a manipulation check, measured on a seven-point Likert scale: "I have the impression that the company focuses on treating employees in a socially responsible way." A $t$-test revealed a significantly higher mean for this item in the internal CSR group $(M=6.04, S D=1.07)$ than in the external CSR group $(M=4.51, S D=1.31), t(273)=10.63, p<.001$. Additionally, we again conducted a two-way ANOVA, which revealed a significant main effect for the luxury manipulation $(F(1,271)=10.14, p=.002)$ and for the CSR manipulation $(F(1,271)=120.69, p<.001)$, as well as a significant interaction effect $(F(1,271)=19.19, p<.001)$. The effect size of the CSR type manipulation was eight times higher $\left(\eta_{\mathrm{p}}{ }^{2}=.31\right)$ than the effect size of the luxury manipulation $\left(\eta_{\mathrm{p}}{ }^{2}=.04\right)$ and four times higher than the effect size of the interaction $\left(\eta_{\mathrm{p}}{ }^{2}=.07\right)$, suggesting that our internal CSR manipulation was successful.

Lastly, we checked for the manipulation of external CSR with the item "I have the impression that the company focuses on making donations to external social causes," measured on a seven-point Likert scale. A significantly higher mean for perceived company-external CSR occurred in the external CSR group $(M=5.48, S D=1.11)$ than in the internal CSR group $(M=4.13, S D=1.57)$, $t(273)=8.27, p<.001$. Furthermore, we again conducted a two-way ANOVA, which revealed a significant main effect of the luxury manipulation $(F(1,271)=9.96$, $p=.002)$ and of the CSR manipulation $(F(1,271)=74.75$, $p<.001)$, but no interaction effect $(F(1,271)=.07$, $p=.796)$. The effect size of the CSR type manipulation was six times higher $\left(\eta_{p}^{2}=.22\right)$ than the effect size of the luxury manipulation $\left(\eta_{\mathrm{p}}^{2}=.04\right)$, suggesting that our CSR manipulation was successful.

Hypothesis testing We began our hypothesis testing with an ANOVA in which luxury (coded as 1 for luxury company and 0 for non-luxury company) and CSR type (coded as 1 for company-internal CSR and 0 for company-external CSR) were the independent variables and loyalty intentions were the dependent variable. The analysis revealed significant main effects of luxury $(F(1,271)=114.67, p<.001)$ and CSR type $(F(1,271)=8.71, p=.003)$, and a significant interaction effect of luxury and CSR type $(F(1,271)=4.14, p=.04)$. Simple effects analyses showed that the type of CSR influenced loyalty intentions in the luxury condition $(F(1,271)=11.75$, $p=.001)$, indicating that loyalty intentions are higher for internal CSR $(M=4.44, S E=.16)$ than external CSR $(M=3.71$, $S E=.14)$. However, the type of CSR did not influence loyalty intentions in the non-luxury condition $(F(1,271)=.45$, $p=.51)$.

Next, we ran a similar analysis with extrinsic CSR attributions as the dependent variable. The analysis revealed a significant main effect of luxury $(F(1,271)=20.29, p<.001)$, a non-significant main effect of CSR type $(F(1,271)=1.01$, $p=.32$ ), and a marginally significant interaction effect of luxury and CSR type $(F(1,271)=3.31, p=.07)$. Simple effects analyses showed that the type of CSR marginally influenced extrinsic CSR attributions in the luxury condition $(F(1,271)=$ $3.77, p=.05)$, indicating that extrinsic CSR attributions are slightly higher for external CSR $(M=4.15, S E=.16)$ than internal CSR $(M=3.68, S E=.18)$. However, the type of CSR did not influence extrinsic CSR attributions in the nonluxury condition $(F(1,271)=.35, p=.55)$. Figure 2 illustrates the interaction effects.

To examine whether the luxury dummy has an indirect effect on loyalty intentions via extrinsic CSR attributions depending on the type of CSR, we ran Model 7 (5000 bootstrap samples) with SPSS Process macro (Hayes 2018) using the luxury dummy as the independent variable, CSR dummy as the moderator, extrinsic CSR attributions as the mediator, and loyalty intentions as the dependent variable. In line with H5, we found a significant moderated mediation effect of the interaction of the CSR and luxury dummies via extrinsic CSR attributions on loyalty intentions (index of moderated mediation $=.22,95 \% \mathrm{CI}: .00, .49$ ), indicating that the negative indirect effect of the luxury dummy on loyalty intentions via extrinsic CSR attributions is more pronounced in the external CSR condition $(b=-.37,95 \%$ CI: $-.63,-.19)$ compared to the internal CSR condition $(b=-.16,95 \% \mathrm{CI}:-.33,-.01)$. We report the correlations between the constructs in Web Appendix L and the results of the full model in Table 4. 


\section{Discussion}

Study 4 provided insights into how luxury companies can attenuate the negative influence of CSR engagement on loyalty intentions. The results show that, for luxury companies, company-internal CSR activities increase customer loyalty compared with company-external CSR activities. The findings also tentatively point to their underlying psychological mechanism, in that company-internal CSR exhibited a marginally significant negative effect on extrinsic CSR attributions. While the results of this study have managerial implications in terms of overcoming the potential pitfalls of CSR in luxury contexts, in order to offer a broader set of managerial implications, we turn to our next study to test an alternative strategy based on brand framing.

\section{Study 5: The framing of luxury brands}

Many luxury companies have a long tradition of engaging in philanthropic donations, engagements, and partnerships; suddenly discontinuing these activities may prove challenging and, in many cases, even irresponsible. Thus, with Study 5 we aimed to provide a viable strategy to circumvent the potential extrinsic CSR attributions resulting from companyexternal CSR, particularly for luxury companies hoping to remain loyal to their partner NGOs and to continue to engage in philanthropic activities. Accordingly, we investigated how luxury companies can mitigate the negative customer outcomes of CSR engagement through brand framing. We focused on an emerging framing strategy that some luxury companies, such as Tesla and Stella McCartney, have already adopted - that is, incorporating sustainability into the core of the brand framing.

\section{Method}

Experimental design and procedure We recruited a sample of 116 U.S. citizens via Prolific. In line with Study 4, we excluded three participants who spent less than three minutes on the questionnaire, as it was unrealistic that these participants would have been able to pay sufficient attention to the questionnaire ( $M_{\text {response time }}=8.75 \mathrm{~min}$.). Hence, the final sample consisted of 113 participants $\left(M_{\mathrm{age}}=30.60\right.$ years, $57.50 \%$ male, $39.80 \%$ female, $2.70 \%$ other). We used a betweensubjects design in which we manipulated the framing of a luxury brand as either exclusivity focused $(n=57)$ or sustainability focused $(n=56)$. We explained to participants that the company wants to make a positive contribution to the world by donating to social causes. All experimental materials are included in Web Appendix J.
Measures After the manipulations, we first measured participants' loyalty intentions before measuring extrinsic CSR attributions using the same scale as in Studies 3 and 4, and finally, we conducted manipulation checks. Both multi-item scales exceeded the threshold value of .70 for Cronbach's alpha (Bagozzi and Yi 1988; Nunnally 1978). All factor loadings were above .72, and both measures met the FornellLarcker requirement in support of discriminant validity. The Appendix provides a comprehensive overview of the measures and the confirmatory factor analysis.

\section{Results}

Manipulation checks To ensure that the manipulations worked as intended, we measured participants' perceptions of the exclusivity and environmental sustainability of the brand with the following items using a seven-point Likert scale: "The products of this company are highly exclusive" and "The products of this company are environmentally friendly." A ttest with the treatment as the independent variable (coded as 0 for exclusivity framing and 1 for sustainability framing) and the manipulation check item as the dependent variable revealed that the products were perceived as significantly more exclusive in the exclusivity framing group $(M=6.21, S D=$ $1.00)$ than in the sustainability framing group $(M=4.61, S D=$ $1.26 ; t(111)=7.51, p<.001)$. Further, the products were perceived as significantly more sustainable in the sustainability framing group $(M=5.96, S D=1.18)$ than in the exclusivity framing group $(M=3.89, S D=1.16), t(111)=9.42, p<.001$. Thus, our manipulations worked as intended.

Hypotheses testing We began testing H6 using a t-test, wherein the grouping variable was the independent variable and loyalty intentions were the dependent variable. In line with our expectations, the analysis revealed that loyalty intentions were significantly higher in the sustainability framing group $(M=5.22, S D=1.00)$ than in the exclusivity framing group $(M=4.16, S D=1.29), t(111)=4.87, p<.001$. In addition, we conducted a t-test using extrinsic CSR attributions as the dependent variable, and the analysis revealed that extrinsic CSR attributions were significantly higher in the exclusivity framing group $(M=3.59, S D=1.43)$ than in the sustainability framing group $(M=3.04, S D=1.39), t(111)=2.07, p=.04$. As a final step, we tested $\mathrm{H} 6$ with a mediation from the treatment variable to loyalty intentions via extrinsic CSR attributions using SPSS Process macro (Hayes 2018, Model 4, 5000 bootstrap samples). The analysis revealed a significant indirect effect (effect $=.16,95 \%$ CI: $.02, .39$ ), thereby lending support to H6. We report the full results of the mediation analysis in Table 4 and the correlations in Web Appendix L. 


\section{Discussion}

In addition to the type of CSR as discussed in Study 4, Study 5 provides a second tool for luxury brand managers to mitigate the negative effects of CSR. These findings reveal that luxury companies can benefit from a brand framing strategy focused around sustainability, as opposed to a more traditional, exclusivity-focused framing strategy. The findings provide empirical support for the proposition that it may be beneficial not only to engage in CSR but also to implement sustainability into the brand framing (Du et al. 2007), particularly for luxury companies (Kapferer and Michaut-Denizeau 2014). The findings also highlight the multifaceted nature of luxury (Kapferer and Michaut 2015) and demonstrate that the different facets of luxury have different consequences for consumer behavior, especially in interaction with other company characteristics and activities.

\section{General discussion}

To elucidate the role of CSR in the luxury context, we conducted five empirical studies. In Study 1 we leveraged a longitudinal secondary dataset and found that, on average, CSR engagement reduces luxury companies' financial performance over several consecutive years. Study 2 revealed that CSR may have harmful effects for luxury companies by triggering customers' extrinsic CSR attributions, which in turn reduce their loyalty intentions. In Study 3, we found that extrinsic CSR attributions are further increased when consumers evaluate a company's CSR after a period of deliberation instead of making an immediate evaluation. Importantly, Studies 4 and 5 examined how luxury companies can mitigate these negative effects of CSR efforts. Study 4 showed that luxury companies can increase customer loyalty by engaging in company-internal, especially employee-focused CSR rather than companyexternal, philanthropic CSR, while Study 5 showed that luxury brands engaging in CSR can benefit from framing the brand as sustainable instead of exclusive.

\section{Theoretical contributions}

As our starting point for this investigation, we noted the growing relevance of companies' CSR activities in luxury contexts and, relatedly, the seemingly opposing findings on the role of CSR in such contexts. Notably, the existing literature on CSR has not addressed the long-term firm- and customer-level outcomes in the luxury context. Hence, by addressing these gaps, our findings advance academic knowledge on multiple fronts. First, and fundamentally, our studies broaden the CSR literature, most of which focuses on non-luxury contexts (Janssen et al. 2014). Our research underlines the need to differentiate between market contexts when exploring the consequences of companies' CSR engagement. While prior CSR research impressively clarifies the diverse benefits of companies' CSR engagement in terms of customer and financial outcomes (e.g., Habel et al. 2016), our examination shows that these findings do not necessarily extrapolate to CSR effectiveness in luxury markets. This notion coincides with the previous research finding that product type (luxury vs. necessity) moderates consumer responses to responsible business practices (White et al. 2012).

Second, our research demonstrates that luxury companies' CSR can evoke extrinsic CSR attributions, which may be highly undesirable for these companies. This finding extends previous research showing the negative effects of CSR on the level of consumers' attitudes in the luxury context (Achabou and Dekhili 2013; Torelli et al. 2012). We further contribute to the literature on CSR attributions (Ellen et al. 2006; Forehand and Grier 2003) by highlighting a new antecedent of extrinsic CSR attributions, namely the use of CSR in luxury contexts. We show that extrinsic CSR attributions are particularly elevated when consumers evaluate a company's CSR activities after a period of deliberation and thereby, we reveal the dynamic nature of extrinsic attributions.

Third, our study responds to the call for a better understanding of the interplay between luxury and CSR (Janssen et al. 2014). While some seminal works have indicated that CSR might be an effective strategy for luxury brands (e.g., Hagtvedt and Patrick 2016; Steinhart et al. 2013; Strahilevitz and Myers 1998), other research has warned that CSR may undermine a luxury brand's image (Torelli et al. 2012) and lower perceptions of luxury products (Achabou and Dekhili 2013). We contribute to the field of marketing by resolving this ambiguity, clearly identifying conditions under which CSR backfires or pays off for luxury brands. Specifically, while CSR may erode the financial performance of luxury companies, elicit extrinsic CSR attributions, and reduce customers' loyalty, this need not be the case. We show how luxury companies can mitigate the negative effects of CSR with the right type of CSR engagement and brand framing. Thus, our findings help managers navigate the use of CSR in luxury contexts and carry other important implications as outlined below.

\section{Managerial implications}

Our finding regarding the negative effects of CSR engagement on luxury companies' sales revenue growth and brand value growth should draw managers' attention to the potential pitfalls of CSR in luxury contexts. Our results imply that, unless carefully implemented, luxury companies' CSR activities can trigger customers' extrinsic CSR attributions, which might, in turn, reduce their loyalty. Therefore, merely investing in CSR without considering the type of CSR and 
the brand framing may actually harm companies' financial performance in the long run. At the same time, the practitioner survey that we conducted revealed that managers are uncertain and tend to have false intuitions about how to implement CSR in the luxury context. For example, when asked whether they would rather invest in companyinternal or company-external CSR activities, $41.70 \%$ chose internal CSR activities, $12.50 \%$ were undecided, and $45.90 \%$ chose external CSR activities.

Using the results of our studies, managers of luxury companies can make better-informed decisions about CSR engagement and avoid the potential pitfalls. Our finding that the CSR of luxury companies reduces loyalty intentions via increased extrinsic CSR attributions highlights the need to design CSR communications or brand framing with a specific focus on minimizing extrinsic CSR attributions. In addition, our results emphasize the importance of careful CSR strategy development; this is particularly relevant for luxury companies that depend on long-term customer loyalty, because if consumers deliberate on a luxury company's CSR activities after the immediate point of purchase, their loyalty intentions can decrease by $33 \%$. However, we present concrete remedies that luxury companies can use to prevent a CSR backlash. While the majority of the managers we surveyed (58\%) expected company-external CSR activities to be more beneficial in terms of customer outcomes, we show that luxury companies are in fact better off directing their efforts toward company-internal, especially employee-focused CSR. Thus, we recommend that managers adopt an "inside-out" approach when developing their CSR whereby employees are the key stakeholder group (Morsing et al. 2008). In other words, luxury companies should start their CSR initiatives within their own four walls first, ensuring a safe and appealing work environment for their employees (Morsing et al. 2008). Our findings imply that adopting such an approach and communicating it to consumers can benefit luxury companies by increasing their customers' loyalty intentions by $20 \%$.

At the same time, we examine which brand framing strategies will benefit companies that still prefer to focus on company-external CSR activities (e.g., due to ongoing commitments to charity organizations). While most managers $(54.40 \%)$ would opt to frame a luxury brand as exclusive, our results show that luxury brands engaging in companyexternal CSR activities can in fact benefit most from framing their brands around sustainability instead of exclusivity (e.g., by carefully developing, implementing, and communicating a higher purpose of their company which is related to sustainability). This type of framing can increase luxury companies' customer loyalty by $25 \%$. In Table 5 , we present a hands-on implementation guide of CSR in luxury contexts based on our managerial implications.

\section{Limitations and suggestions for future research}

Like any research, our study is not without limitations. In Study 2 we found that CSR in the luxury context did not influence loyalty directly but did so indirectly via extrinsic attributions (i.e., there was an indirect-only mediation; Zhao et al. 2010). Future studies might overcome this limitation by employing controlled settings with larger sample sizes while studying the interplay of CSR and luxury. Further, a countervailing effect to our results might occur at the point of sale (i.e., consumers' feelings of reduced guilt for a luxury purchase due to CSR may lead to positive consumer outcomes) (Hagtvedt and Patrick 2016). Future research should account for both mechanisms simultaneously to understand their interplay at the point of sale. Additionally, in Studies $3-5$, which were fictional scenario experiments, we were not able to include a non-CSR control group because, for a fictive company, participants in such a condition lack the necessary information to make CSR attributions. Notably, we included a non-CSR control group in Study 2 with the expectation that the participants would have enough pre-existing evaluations of the company's CSR activities to answer questions about extrinsic CSR attributions because we collaborated with a real company. Future experiments would benefit from the inclusion of non-CSR control groups, testing slightly altered conceptual models (e.g., not including CSR attributions as a mediator).

Moreover, in line with Schnider et al. (2018), we manipulated deliberation in Study 3 so that the participants discussed a luxury company's CSR activities with the person sitting next to them. Thus, this manipulation involved a social element, and participants may have influenced each other's opinions in ways beyond our control. While consumers may naturally engage in such discussions about companies, future studies could also consider a different manipulation of deliberation that excludes social interaction. In addition, we did not include a comparison with a non-luxury product in Study 3 because we were specifically interested in extending the results of Study 2 by revealing the mechanism that drives the longerterm influence of CSR and luxury on loyalty intentions. However, we encourage future researchers to also consider the effect of CSR deliberation on customer outcomes in nonluxury contexts.

Finally, we suggest that future studies investigate even more strategies for luxury companies to engage in CSR without suffering from customers' extrinsic CSR attributions. For instance, the conflict between the concepts of CSR and luxury might be resolved by framing CSR communication in such a way that it complements the luxury concept instead of contradicting it (e.g., "as a luxury company, we engage in CSR actions because we have the strength and means to do so"). Additionally, luxury companies could employ a variety of justifications for their CSR efforts, such as strong social or 
Table 5 Summary of recommendations for managers in the luxury context

\begin{tabular}{ll} 
Managerially relevant questions & Relevant study insights \\
\hline $\begin{array}{l}\text { Are you considering engaging in CSR activities } \\
\text { and are you interested in the firm-level out- } \\
\text { comes? }\end{array}$ & $\begin{array}{l}\text { Instead of satisfying stakeholder demands for } \\
\text { socially responsible luxury, CSR engagement } \\
\text { may harm sales revenue growth and brand } \\
\text { value growth of luxury companies (Study 1). }\end{array}$
\end{tabular}

Recommendations for luxury brand managers

Are you considering engaging in CSR activities and are you interested in the customer-level outcomes? Is it possible to direct your CSR efforts toward company-internal CSR?
Is your business model based on long-term customer loyalty?
For luxury brands, engaging in company-external CSR activities may be perceived as extrinsically motivated by consumers, which can subsequently reduce their loyalty intentions (Study 2). However, customer loyalty can increase by $20 \%$ if a luxury company engages in company-internal, especially employee-focused CSR instead (Study 4).
- Unless carefully implemented, CSR engagement may have negative consequences for the financial performance of your company.

- CSR engagement is recommended in the light of increased stakeholder expectations. However, consider following our recommendations to avoid its negative firm-level consequences and instead reap the potential benefits.

- Instead of engaging in company-external CSR like donations or sponsorships, engage in company-internal, especially employee-focused CSR (e.g., employee health and wellbeing, work safety, employee training and development, competitive compensation, mentorship programs, good and flexible working conditions). This type of CSR engagement will decrease extrinsic attributions and enhance consumer outcomes (Schons et al. 2017).

- Intensively train your frontline employees to actively communicate this commitment to consumers who are interested in this topic, as previous research has identified companies' own employees as the most credible source of CSR information (Korschun et al. 2014).

Frontline employees should communicate the CSR information in a customer-oriented manner (Alavi et al. 2018).

- Further, consider incentivizing line managers, as they may be crucial in ensuring employees' willingness to communicate CSR to consumers (Edinger-Schons et al. 2019; Wieseke et al. 2011).

- If your business model is based on long-term relationships with consumers, it is especially crucial to implement the right kind of CSR strategy and make consumers aware of it.

- Actively communicate about company-internal CSR activities which improve the social responsibility of your business processes and engage your employees to be CSR ambassadors.

- Consider engaging loyal customers directly in the CSR strategy through online channels and social media, e.g., by asking them for feedback or actively involving them in developing the company's CSR mission. This will enhance consumers' buy-in and support for the activities (Edinger-Schons et al. 2020; Morsing and Schultz 2006).

- If you prefer to focus on company-external CSR activities (e.g., because this has traditionally been the focus of your CSR strategy and you do not want to discontinue this commitment), consider framing your brand as sustainable instead of exclusive to enhance customer loyalty.

- For example, communicate about the brand as having a specific higher purpose that is related 
Table 5 (continued)

to sustainability (which should be carefully developed based on stakeholder engagement and materiality analyses) and/or committing to certain sustainable development goals (Gartenberg et al. 2019).

- When doing so, make sure to consistently live up to your promises in terms of sustainability, i.e., to "walk the talk" (Schons and Steinmeier 2016). For example, make sure that your supply chain does not involve human rights infringements, use ecological and animal-friendly materials, consider carbon offsetting of web shop orders, and reduce the use of plastic packaging of your products.

environmental brand values, an intrinsic willingness to contribute to society, a long tradition of supporting a certain cause, or the founder's interest in the supported cause. Communicating specific reasons for the CSR engagement may directly influence CSR attributions, loyalty, and subsequently, firm performance. We encourage future researchers to explore these compelling possibilities.

Funding Open access funding provided by LUT University.

\section{Appendix}

Table 6 Measures and summaries of the studies

\begin{tabular}{|c|c|c|c|c|}
\hline Constructs & Items & FL & $\mathrm{AVE} / \mathrm{CR} / \mathrm{CA}$ & Goal and key insights of study \\
\hline \multicolumn{5}{|l|}{ STUDY 1} \\
\hline CSR & $\begin{array}{l}\text { The aggregate CSR score attained from the } \\
\text { ASSET4ESG database }\end{array}$ & l & l & \multirow{3}{*}{$\begin{array}{l}\text { Goal: To explore the effect of CSR on } \\
\text { long-term financial performance of } \\
\text { luxury companies } \\
\text { Key insight: CSR reduces the sales } \\
\text { revenue growth and brand value } \\
\text { growth of luxury companies in the } \\
\text { long term (i.e., over a period of } \\
\text { multiple years) }\end{array}$} \\
\hline Luxury & $\begin{array}{l}\text { Coded on a } 1-7 \text { scale by two independent } \\
\text { researchers based on the price, prestige, and } \\
\text { quality of the firm's brands and products }\end{array}$ & l & $.81^{\mathrm{a}}$ & \\
\hline Sales Revenue Growth & $\begin{array}{l}\text { Derived over consecutive years from } \\
\text { Thomson Reuters' Datastream }\end{array}$ & l & / & \\
\hline \multicolumn{5}{|l|}{ STUDY 2} \\
\hline $\begin{array}{l}\text { Extrinsic CSR } \\
\text { Attributions } \\
\text { Loyalty Intentions }\end{array}$ & $\begin{array}{l}\text { I believe that the company only engages in } \\
\text { CSR to attract new customers. } \\
\text { (1) The likelihood that I will buy a car from } \\
\text { this company in the future is very high. } \\
\text { (2) The likelihood of recommending this } \\
\text { company to my friends is very high. }\end{array}$ & l & $-/-1.70$ & \multirow[t]{2}{*}{$\begin{array}{l}\text { Goal: To understand which } \\
\text { customer-level psychological pro- } \\
\text { cesses underlie the results of Study } 1 \\
\text { Key insight: Extrinsic CSR attributions } \\
\text { increase when a luxury company } \\
\text { communicates about CSR, resulting } \\
\text { in lower loyalty intentions }\end{array}$} \\
\hline \multicolumn{4}{|l|}{ STUDY 3} & \\
\hline Loyalty Intentions & $\begin{array}{l}\text { (1) I would say positive things about the } \\
\text { company to other people. } \\
\text { (2) I would recommend the company to } \\
\text { someone who seeks my advice. } \\
\text { (3) I would encourage friends and relatives to } \\
\text { purchase from the company. } \\
\text { (4) I would consider the company my first } \\
\text { choice to buy a wristwatch. }\end{array}$ & $\begin{array}{l}\text { (1) } .91 \\
\text { (2) } .94 \\
\text { (3) } .90 \\
\text { (4) } .72 \\
\text { (5) } .75\end{array}$ & $.72 / .93 / .93$ & $\begin{array}{l}\text { Goal: To investigate which } \\
\text { consumer-level psychological pro- } \\
\text { cesses potentially underlie the nega- } \\
\text { tive long-term effect of CSR on lux- } \\
\text { ury brands' financial performance, } \\
\text { focusing on the role of deliberation } \\
\text { on a luxury company's CSR en- } \\
\text { gagement }\end{array}$ \\
\hline
\end{tabular}


(continued)

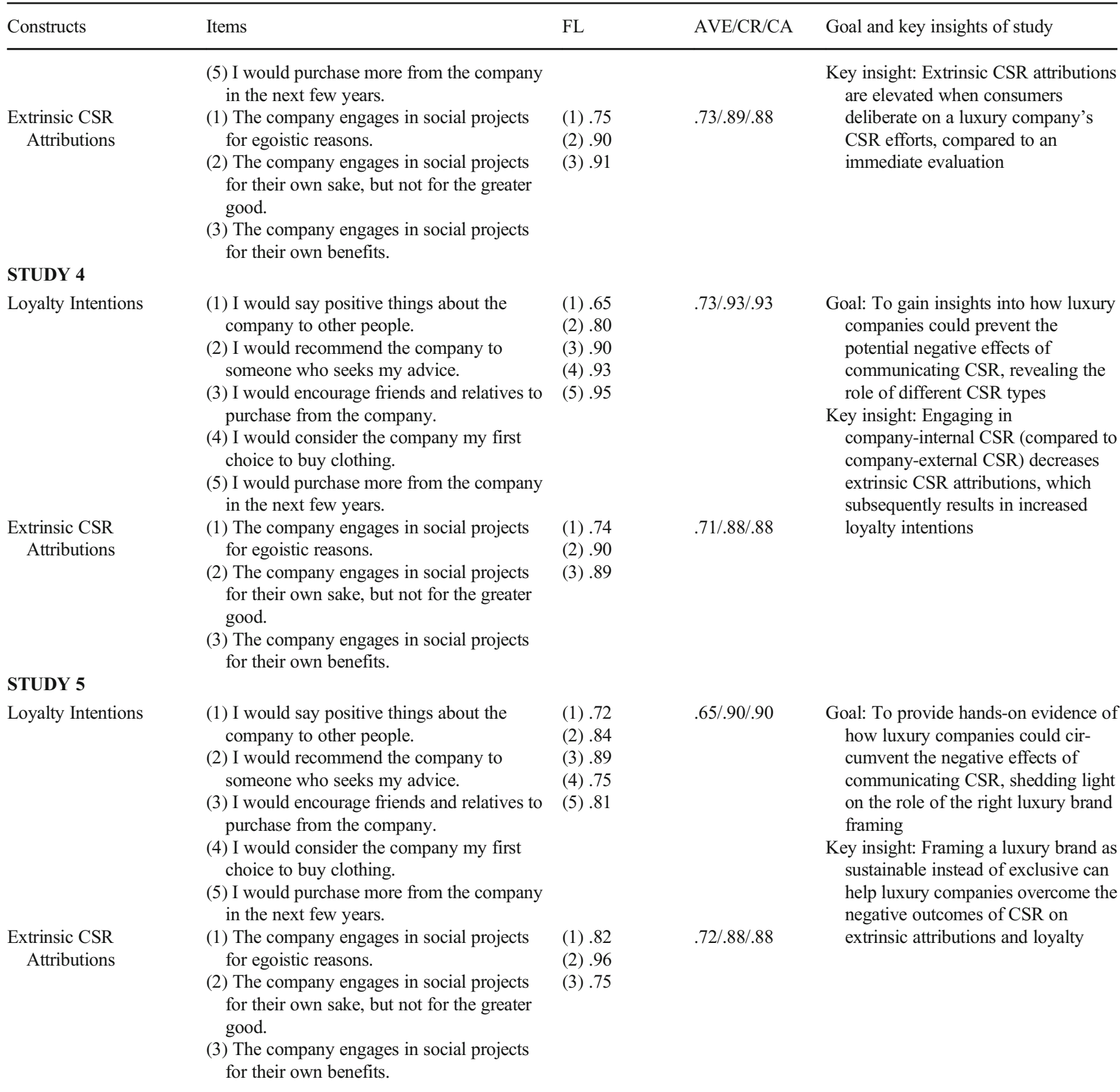

All measures for which an AVE was available fulfilled the Fornell and Larcker (1981) requirement in support of discriminant validity

Sources: Luxury: Dubois et al. (2001); extrinsic CSR attributions in Study 2: Ellen et al. (2002); extrinsic CSR attributions in Studies 3-5: Habel et al. (2016); loyalty intentions: Zeithaml et al. (1996)

$F L$, factor loadings; $A V E$, average variance extracted; $C R$, composite reliability; $C A$, Cronbach's alpha

${ }^{a}$ The value refers to the interrater reliability of the two coders 
Open Access This article is licensed under a Creative Commons Attribution 4.0 International License, which permits use, sharing, adaptation, distribution and reproduction in any medium or format, as long as you give appropriate credit to the original author(s) and the source, provide a link to the Creative Commons licence, and indicate if changes were made. The images or other third party material in this article are included in the article's Creative Commons licence, unless indicated otherwise in a credit line to the material. If material is not included in the article's Creative Commons licence and your intended use is not permitted by statutory regulation or exceeds the permitted use, you will need to obtain permission directly from the copyright holder. To view a copy of this licence, visit http://creativecommons.org/licenses/by/4.0/.

\section{References}

Achabou, M. A., \& Dekhili, S. (2013). Luxury and sustainable development: Is there a match? Journal of Business Research, 66(10), 1896-1903.

Alavi, S., Habel, J., Schmitz, C., Richter, B., \& Wieseke, J. (2018). The risky side of inspirational appeals in personal selling: When do customers infer ulterior salesperson motives? Journal of Personal Selling \& Sales Management, 38(3), 323-343.

Babin, L. A., Babin, B. J., \& Boles, J. S. (1999). The effects of consumer perceptions of the salesperson, product and dealer on purchase intentions. Journal of Retailing and Consumer Services, 6(2), 91-97.

Bagozzi, R. P., \& Yi, Y. (1988). On the evaluation of structural equation models. Journal of the Academy of Marketing Science, 16(1), 74-94.

Becker-Olsen, K. L., Cudmore, B. A., \& Hill, R. P. (2006). The impact of perceived corporate social responsibility on consumer behavior. Journal of Business Research, 59(1), 46-53.

Bellezza, S., Gino, F., \& Keinan, A. (2014). The red sneakers effect: Inferring status and competence from signals of nonconformity. Journal of Consumer Research, 41(1), 35-54.

Bernerth, J. B., Cole, M. S., Taylor, E. C., \& Walker, H. J. (2018). Control variables in leadership research: A qualitative and quantitative review. Journal of Management, 44(1), 131-160.

Bhattacharya, C. B., \& Sen, S. (2003). Consumer-company identification: A framework for understanding consumers' relationships with companies. Journal of Marketing, 67(2), 76-88.

Bhattacharya, C. B., \& Sen, S. (2004). Doing better at doing good: When, why, and how consumers respond to corporate social initiatives. California Management Review, 47(1), 9-24.

Bindl, U. K., Parker, S. K., \& Totterdell, P. (2012). Fuel of the self-starter: How mood relates to proactive goal regulation. Journal of Applied Psychology, 97(1), 134-150.

Bollen, K. A., \& Curran, P. J. (2006). Latent curve models: A structural equation perspective. New Jersey: John Wiley \& Sons.

Brexendorf, T. O., Mühlmeier, S., Tomczak, T., \& Eisend, M. (2010). The impact of sales encounters on brand loyalty. Journal of Business Research, 63(11), 1148-1155.

Buchanan, L., Simmons, C. J., \& Bickart, B. A. (1999). Brand equity dilution: Retailer display and context brand effects. Journal of Marketing Research, 36(3), 345-355.

Burberry. (2017). Responsibility reflections. Our responsibility journey, 2012-2017 Retrieved March 27, 2018 from https:/www. burberryplc.com/content/dam/burberry/corporate/Responsibility/ Performance/Docs/Burberry\%20Responsibility\%20Report\% 202012-17.pdf.

Campbell, M. C., \& Kirmani, A. (2000). Consumers' use of persuasion knowledge: The effects of accessibility and cognitive capacity on perceptions of an influence agent. Journal of Consumer Research, 27(1), 69-83.
Capon, N., Farley, J. U., \& Hoenig, S. (1990). Determinants of financial performance: A meta-analysis. Management Science, 36(10), 11431159.

Chan, D., \& Schmitt, N. (2000). Interindividual differences in intraindividual changes in proactivity during organizational entry: A latent growth modeling approach to understanding newcomer adaptation. Journal of Applied Psychology, 85(2), 190-210.

Dion, D., \& Arnould, E. (2011). Retail luxury strategy: Assembling charisma through art and magic. Journal of Retailing, 87(4), 502-520.

Du, S., Bhattacharya, C. B., \& Sen, S. (2007). Reaping relational rewards from corporate social responsibility: The role of competitive positioning. International Journal of Research in Marketing, 24(3), 224-241.

Du, S., Bhattacharya, C. B., \& Sen, S. (2010). Maximizing business returns to corporate social responsibility (CSR): The role of CSR communication. International Journal of Management Reviews, 12(1), 8-19.

Dubois, B., Laurent, G., \& Czellar, S. (2001). Consumer rapport to luxury: Analyzing complex and ambivalent attitudes. Groupe HEC: Jouy-en-Josas.

Edinger-Schons, L. M., Lengler-Graiff, L., Scheidler, S., \& Wieseke, J. (2019). Frontline employees as corporate social responsibility (CSR) ambassadors: A quasi-field experiment. Journal of Business Ethics, 157(2), 359-373.

Edinger-Schons, L. M., Lengler-Graiff, L., Scheidler, S., Mende, G., \& Wieseke, J. (2020). Listen to the voice of the customer-First steps towards stakeholder democracy. Business Ethics: A European Review, 29(3), 510-527.

Ellen, P. S., Mohr, L. A., \& Webb, D. J. (2002). Pure or mixed motives: Consumer attributions for corporate pro-social marketing programs. In P. A. Keller \& D. W. Rook (Eds.), Advances in consumer research (pp. 322-324). Valdosta: Association for Consumer Research.

Ellen, P. S., Webb, D. J., \& Mohr, L. A. (2006). Building corporate associations: Consumer attributions for corporate socially responsible programs. Journal of the Academy of Marketing Science, 34(2), $147-157$.

Epstein-Reeves, J. (2010). Consumers overwhelmingly want CSR. Retrieved 28 June, 2018 from https://www.forbes.com/sites/csr/ 2010/12/15/new-study-consumers-demand-companies-implementcsr-programs/\#178bb98065c7.

Forehand, M. R., \& Grier, S. (2003). When is honesty the best policy? The effect of stated company intent on consumer skepticism. Journal of Consumer Psychology, 13(3), 349-356.

Fornell, C., \& Larcker, D. F. (1981). Structural equation models with unobservable variables and measurement error: Algebra and statistics. Journal of Marketing Research, 18(3), 382-388.

Gartenberg, C., Prat, A., \& Serafeim, G. (2019). Corporate purpose and financial performance. Organization Science, 30(1), 1-18.

Geuens, M., \& De Pelsmacker, P. (2017). Planning and conducting experimental advertising research and questionnaire design. Journal of Advertising, 46(1), 83-100.

Groth, M., Hennig-Thurau, T., \& Walsh, G. (2009). Customer reactions to emotional labor: The roles of employee acting strategies and customer detection accuracy. Academy of Management Journal, 52(5), 958-974.

Habel, J., Schons, L. M., Alavi, S., \& Wieseke, J. (2016). Warm glow or extra charge? The ambivalent effect of corporate social responsibility activities on customers' perceived price fairness. Journal of Marketing, 80(1), 84-105.

Habel, J., Alavi, S., \& Pick, D. (2017). When serving customers includes correcting them: Understanding the ambivalent effects of enforcing service rules. International Journal of Research in Marketing, 34(4), 919-941.

Hagtvedt, H., \& Patrick, V. M. (2009). The broad embrace of luxury: Hedonic potential as a driver of brand extendibility. Journal of Consumer Psychology, 19(4), 608-618. 
Hagtvedt, H., \& Patrick, V. M. (2016). Gilt and guilt: Should luxury and charity partner at the point of sale? Journal of Retailing, 92(1), 56-64.

Hameed, I., Riaz, Z., Arain, G. A., \& Farooq, O. (2016). How do internal and external CSR affect employees' organizational identification? A perspective from the group engagement model. Frontiers in Psychology, 7, 1-13.

Hayes, A. F. (2018). Introduction to mediation, moderation, and conditional process analysis. New York: Guilford Press.

Hennig-Thurau, T., Groth, M., Paul, M., \& Gremler, D. D. (2006). Are all smiles created equal? How emotional contagion and emotional labor affect service relationships. Journal of Marketing, 70(3), 58-73.

Hildebrand, D., DeMotta, Y., Sen, S., \& Valenzuela, A. (2017). Consumer responses to corporate social responsibility (CSR) contribution type. Journal of Consumer Research, 44(4), 738-758.

Hudders, L., Pandelaere, M., \& Vyncke, P. (2013). Consumer meaning making. International Journal of Market Research, 55(3), 391-412.

Janssen, C., Vanhamme, J., Lindgreen, A., \& Lefebvre, C. (2014). The catch-22 of responsible luxury: Effects of luxury product characteristics on consumers' perception of fit with corporate social responsibility. Journal of Business Ethics, 119(1), 45-57.

Janssen, C., Vanhamme, J., \& Leblanc, S. (2017). Should luxury brands say it out loud? Brand conspicuousness and consumer perceptions of responsible luxury. Journal of Business Research, 77, 167-174.

Kapferer, J. N., \& Michaut, A. (2015). Luxury and sustainability: A common future? The match depends on how consumers define luxury. Luxury Research Journal, 1(1), 3-17.

Kapferer, J. N., \& Michaut-Denizeau, A. (2014). Is luxury compatible with sustainability? Luxury consumers' viewpoint. Journal of Brand Management, 21(1), 1-22.

Keiningham, T. L., Aksoy, L., Cooil, B., \& Andreassen, T. W. (2008). Linking customer loyalty to growth. MIT Sloan Management Review, 49(4), 51-57.

Klarmann, M., \& Feurer, S. (2018). Control variables in marketing research. Marketing ZFP, 40(2), 26-40.

Ko, E., Costello, J. P., \& Taylor, C. R. (2017). What is a luxury brand? A new definition and review of the literature. Journal of Business Research, 99(June), 405-413.

Korschun, D., Bhattacharya, C. B., \& Swain, S. D. (2014). Corporate social responsibility, customer orientation, and the job performance of frontline employees. Journal of Marketing, 78(3), 20-37.

McGuire, J. B., Sundgren, A., \& Schneeweis, T. (1988). Corporate social responsibility and firm financial performance. Academy of Management Journal, 31(4), 854-872.

McWilliams, A., \& Siegel, D. (2001). Corporate social responsibility: A theory of the firm perspective. Academy of Management Review, 26(1), 117-127.

Morsing, M., \& Schultz, M. (2006). Corporate social responsibility communication: Stakeholder information, response and involvement strategies. Business ethics: A European review, 15(4), 323-338.

Morsing, M., Schultz, M., \& Nielsen, K. U. (2008). The 'catch 22'of communicating CSR: Findings from a Danish study. Journal of Marketing Communications, 14(2), 97-111.

Nielsen (2014). Doing well by doing good. Retrieved June 28, 2018 from https:/www.nielsen.com/content/dam/nielsenglobal/jp/docs/report/ $2014 /$ Nielsen $\% 20$ Global $\% 20$ Corporate $\% 20$ Social $\%$ 20Responsibility\%20Report\%20-\%20June\%202014.pdf.

Nunnally, J. C. (1978). Psychometric theory. New York: McGraw-Hill.

Öberseder, M., Schlegelmilch, B. B., \& Gruber, V. (2011). Why don't consumers care about CSR? A qualitative study exploring the role of CSR in consumption decisions. Journal of Business Ethics, 104(4), 449-460.

Palmatier, R. W., Houston, M. B., Dant, R. P., \& Grewal, D. (2013). Relationship velocity: Toward a theory of relationship dynamics. Journal of Marketing, 77(1), 13-30.
Peloza, J., \& Shang, J. (2011). How can corporate social responsibility activities create value for stakeholders? A systematic review. Journal of the Academy of Marketing Science, 39(1), 117-135.

Perdue, B. C., \& Summers, J. O. (1986). Checking the success of manipulations in marketing experiments. Journal of Marketing Research, 23(4), 317-326.

Reichheld, F. F., \& Sasser Jr., W. E. (1990). Zero defections: Quality comes to services. Harvard Business Review, 68(5), 105-111.

Reinartz, W. J., \& Kumar, V. (2000). On the profitability of long-life customers in a noncontractual setting: An empirical investigation and implications for marketing. Journal of Marketing, 64(4), 17-35.

Reynolds, K. E., \& Beatty, S. E. (1999). Customer benefits and company consequences of customer-salesperson relationships in retailing. Journal of Retailing, 75(1), 11-32.

Richemont. (2017). Corporate Social Responsibility, 2017 Retrieved March 27, 2018 from https://www.richemont.com/images/csr/ 2017/csr_report_2017.pdf.

Rifon, N. J., Choi, S. M., Trimble, C. S., \& Li, H. (2004). Congruence effects in sponsorship: The mediating role of sponsor credibility and consumer attributions of sponsor motive. Journal of Advertising, 33(1), 30-42.

Schmitz, C., Friess, M., Alavi, S., \& Habel, J. (2020). Understanding the impact of relationship disruptions. Journal of Marketing, 84(1), 6687.

Schnider, R., Haack, P., and Scherer, A. G. (2018). Legitimacy judgments about corporate tax avoidance: A deliberation experiment. Paper presented at the Academy of Management Annual Conference 2018, Chicago, IL.

Schons, L., \& Steinmeier, M. (2016). Walk the talk? How symbolic and substantive CSR actions affect firm performance depending on stakeholder proximity. Corporate Social Responsibility and Environmental Management, 23(6), 358-372.

Schons, L. M., Scheidler, S., \& Bartels, J. (2017). Tell me how you treat your employees. Journal of Marketing Behavior, 3(1), 1-37.

Sen, S., \& Bhattacharya, C. B. (2001). Does doing good always lead to doing better? Consumer reactions to corporate social responsibility. Journal of Marketing Research, 38(2), 225-243.

Skarmeas, D., \& Leonidou, C. N. (2013). When consumers doubt, watch out! The role of CSR skepticism. Journal of Business Research, 66(10), 1831-1838.

Steenkamp, J.-B., \& Baumgartner, H. (2000). On the use of structural equation models for marketing modeling. International Journal of Research in Marketing, 17(2), 195-202.

Steinhart, Y., Ayalon, O., \& Puterman, H. (2013). The effect of an environmental claim on consumers' perceptions about luxury and utilitarian products. Journal of Cleaner Production, 53(August), 277286.

Strahilevitz, M., \& Myers, J. G. (1998). Donations to charity as purchase incentives: How well they work may depend on what you are trying to sell. Journal of Consumer Research, 24(4), 434-446.

Suh, J. C., \& Yi, Y. (2006). When brand attitudes affect the customer satisfaction-loyalty relation: The moderating role of product involvement. Journal of Consumer Psychology, 16(2), 145-155.

Suri, R., \& Monroe, K. B. (2003). The effects of time constraints on consumers' judgments of prices and products. Journal of Consumer Research, 30(1), 92-104.

Taylor, V. A., \& Bearden, W. O. (2002). The effects of price on brand extension evaluations: The moderating role of extension similarity. Journal of the Academy of Marketing Science, 30(2), 131-140.

Thomas, R. W., Soutar, G. N., \& Ryan, M. M. (2001). The selling orientation-customer orientation (SOCO) scale: A proposed short form. Journal of Personal Selling \& Sales Management, 21(1), 63-69.

Thomson Reuters (2016). Thomson Reuters' ASSET4ESG Database. Retrieved August 18, 2016 from http://thomsonreuters.com/esgresearch-data/. 
Tiffany \& Co. (2016). Sustainability report 2016. Retrieved March 27, 2018 from http://www.tiffany.com/sustainability/CSRFullReport. aspx.

Torelli, C. J., Monga, A. B., \& Kaikati, A. M. (2012). Doing poorly by doing good: Corporate social responsibility and brand concepts. Journal of Consumer Research, 38(5), 948-963.

Turker, D. (2009). How corporate social responsibility influences organizational commitment. Journal of Business Ethics, 89(2), 189-204.

Vlachos, P. A., Tsamakos, A., Vrechopoulos, A. P., \& Avramidis, P. K. (2009). Corporate social responsibility: Attributions, loyalty, and the mediating role of trust. Journal of the Academy of Marketing Science, 37(2), 170-180.

Vlachos, P. A., Krepapa, A., Panagopoulos, N. G., \& Tsamakos, A. (2013). Curvilinear effects of corporate social responsibility and benevolence on loyalty. Corporate Reputation Review, 16(4), 248-262.

Voyer, B. G., \& Beckham, D. (2014). Can sustainability be luxurious? A mixed-method investigation of implicit and explicit attitudes towards sustainable luxury consumption. In J. Cotte \& S. Wood (Eds.), Advances in consumer research (pp. 245-250). Duluth: Association for Consumer Research.

Waddock, S. A., \& Graves, S. B. (1997). The corporate social performance-financial performance link. Strategic Management Journal, 18(4), 303-319.

White, K., MacDonnell, R., \& Ellard, J. H. (2012). Belief in a just world: Consumer intentions and behaviors toward ethical products. Journal of Marketing, 76(1), 103-118.
Wieseke, J., Kraus, F., Alavi, S. H., \& Kessler-Thönes, T. (2011). How leaders' motivation transfers to customer service representatives. Journal of Service Research, 14(2), 214-233.

Wieseke, J., Alavi, S., \& Habel, J. (2014). Willing to pay more, eager to pay less: The role of customer loyalty in price negotiations. Journal of Marketing, 78(6), 17-37.

Winston, A. (2016). Luxury brands can no longer ignore sustainability. Harvard Business Review. Retrieved March $13^{\text {th }}$, 2020, from: https://hbr.org/2016/02/luxury-brands-can-no-longer-ignoresustainability\#comment-section.

Wood, D., Harms, P. D., Lowman, G. H., \& DeSimone, J. A. (2017). Response speed and response consistency as mutually validating indicators of data quality in online samples. Social Psychological and Personality Science, 8(4), 454-464.

World Commission on Environment and Development. (1987). Our common future. Oxford: Oxford University Press.

Zeithaml, V. A., Berry, L. L., \& Parasuraman, A. (1996). The behavioral consequences of service quality. Journal of Marketing, 60(2), 3146.

Zhao, X., Lynch Jr., J. G., \& Chen, Q. (2010). Reconsidering Baron and Kenny: Myths and truths about mediation analysis. Journal of Consumer Research, 37(2), 197-206.

Publisher's note Springer Nature remains neutral with regard to jurisdictional claims in published maps and institutional affiliations. 